\title{
Effects of volcanic and hydrologic processes on forest vegetation: Chaitén Volcano, Chile
}

\author{
Frederick J. Swanson ${ }^{1}$, Julia A. Jones ${ }^{2}$, Charles M. Crisafulli ${ }^{3}$, Antonio Lara ${ }^{4}$ \\ ${ }^{1}$ United States Forest Service, Pacific Northwest Research Station, 3200 Jefferson Way, Corvallis, OR 97331, USA. \\ fred.swanson@oregonstate.edu \\ ${ }^{2}$ College of Earth, Ocean, and Atmospheric Sciences, Oregon State University, 104 CEOAS Administration Building, Corvallis, OR \\ 97331, USA. \\ geojulia@comcast.net \\ ${ }^{3}$ United States Forest Service, Pacific Northwest Research Station, 3625 93rd Ave SW, Olympia, Washington, 98512, USA. \\ ccrisafulli@fs.fed.us \\ ${ }^{4}$ Facultad de Ciencias Forestales y Recursos Naturales, Universidad Austral de Chile, Casilla 567, Isla Teja, Valdivia, Chile. \\ antoniolara@uach.edu
}

\begin{abstract}
The 2008-2009 eruption of Chaitén Volcano (Chile) involved a variety of volcanic and associated hydrologic processes that damaged nearby forests. These processes included coarse (gravel) and fine (silt to sand) tephra fall, a laterally directed blast, fluvial deposition of remobilized tephra, a variety of low-temperature mass-movement processes, and a pyroclastic flow. Each of these geophysical processes constitutes a type of ecosystem disturbance which involves a distinctive suite of disturbance mechanisms, namely burial by tephra and sediment, heating, abrasion, impact force, and canopy loading (accumulation of tephra in tree crowns). Each process affected specific areas, and created patches and disturbance gradients in the forest landscape. Coarse tephra ('gravel rain', $>5 \mathrm{~cm}$ depth) abraded foliage from tree canopies over an area of approximately $50 \mathrm{~km}^{2}$ north-northeast of the vent. Fine tephra ( $>10 \mathrm{~cm}$ depth) accumulated in tree crowns and led to breakage of branches in old forest and bowing of flexible, young trees over an area of about $480 \mathrm{~km}^{2}$. A directed blast down the north flank of the volcano damaged forest over an area of $4 \mathrm{~km}^{2}$. This blast zone included an area of tree removal near the crater rim, toppled forest farther down the slope, and standing, scorched forest around the blast perimeter. Fluvial deposition of $>100 \mathrm{~cm}$ of remobilized tephra, beginning about 10 days after initiation of the eruption, buried floodplain forest in distinct, elongate streamside patches covering $5 \mathrm{~km}^{2}$ of the lower $19 \mathrm{~km}$ of the Rayas River and several $\mathrm{km}^{2}$ of the lower Chaitén River. Across this array of disturbance processes the fate of affected trees varied from complete mortality in the tree removal and pyroclastic flow areas, to no mortality in areas of thin tephra fall deposits. Tree damage included defoliation, loss of branches, snapping of tree trunks, abrasion of bark and ephiphytes, and uprooting. Damaged trees sprouted from epicormic buds located in trunks and branches, but sprouting varied over time among disturbance mechanisms and species. Although some effects of the Chaitén eruption are very similar to those from the 1980 eruption of Mount St. Helens (USA), interactions between biota and geophysical processes at Chaitén produced some unique effects. Examination of vegetation response helps interpret geophysical processes, and disturbance mechanisms influence early stages of biotic response to an eruption.
\end{abstract}


RESUMEN. Efectos de los procesos volcánicos e hidrológicos sobre la vegetación forestal: El volcán Chaitén, Chile. La erupción del volcán Chaitén (Chile) en 2008-2009 involucró una variedad de procesos volcánicos e hidrológicos asociados que dañaron los bosques aledaños. Estos procesos incluyeron la caída de material grueso (grava), fino (limo y arena) y tefra, una explosión con una dirección lateral que derribó superficies de bosques (blast), depositación fluvial de tefra removilizada, un conjunto de procesos de movimiento en masa de baja temperatura y un flujo piroclástico. Cada uno de estos procesos geofísicos constituye un tipo de disturbio (alteración) de los ecosistemas que involucra una variedad de mecanismos, como por ejemplo enterramiento de árboles por tefra y sedimentos, calentamiento, abrasion, fuerza de impacto y carga de tefra sobre la copa de los árboles. Cada proceso afectó áreas específicas y creó parches y gradientes de disturbio en el paisaje. La tefra gruesa ('lluvia de grava', $>5 \mathrm{~cm}$ de profundidad) erosionó el follaje del dosel arbóreo en una zona de aproximadamente $50 \mathrm{~km}^{2}$ hacia el nor-noreste de la apertura volcánica (vent). La tefra fina ( $>10 \mathrm{~cm}$ de profundidad) se acumuló en la copa de los árboles lo que quebró las ramas de los árboles viejos y arqueó los árboles jóvenes en un área de aproximadamente $480 \mathrm{~km}^{2}$. Una explosión (blast) en el flanco norte del volcán dañó los bosques en un área de $4 \mathrm{~km}^{2}$. Esta área incluyó un sector de remoción de los árboles cerca del borde del cráter, derribó los bosques en los sectores más bajas de la ladera y dejó bosques quemados que permanecieron en pie alrededor del perímetro de explosión. La depositación fluvial de $>100 \mathrm{~cm}$ de profundidad de tefra removilizada, que empezó aproximadamente 10 días después del inicio de la erupción, sepultó parches de bosques en los planos aluviales a lo largo de los 19 km del curso inferior del río Rayas, cubriendo $5 \mathrm{~km}^{2}$ y varios $\mathrm{km}^{2}$ del curso inferior del río Chaitén. A través de este arreglo de procesos de disturbios, el destino de los árboles afectados varió desde la mortalidad completa en las áreas de remoción de árboles y de flujos piroclásticos, a ninguna mortalidad en los sectores de caída y depositación de tefra fina. El daño a los árboles incluyó defoliación, pérdida de ramas, quiebre de troncos, abrasión de corteza y epífitas y desarraigamiento. Parte de los árboles dañados rebrotaron a partir de yemas epicórmicas en los troncos y ramas y el rebrote a través del tiempo, según los mecanismos de disturbio y especie. A pesar de que algunos efectos de la erupción del volcán Chaitén son muy similares a los de la erupción del Monte Santa Helena (USA) en 1980, la biota y los procesos geofísicos del primero produjeron algunos efectos únicos.

Palabras clave: Impactos ambientales, Respuesta de la vegetación, Impactos sobre recursos naturales, Perturbaciones ecológicas, Ecología del paisaje.

\section{Introduction}

Explosive volcanism involves a variety of volcanic and associated hydrological processes with many environmental effects (Ayris and Delmelle, 2012). When such eruptions occur, a synthesis of geology, ecology, and geography perspectives helps reveal the nature of volcanic and hydrologic processes, their effects on vegetation, and the patterning of those effects on the landscape (e.g., Dale et al., 2005). In the terminology of ecologists, geophysical processes act as disturbance agents that disrupt ecosystems (White and Pickett, 1985). In the case of a volcanic eruption, an individual primary disturbance type (e.g., volcanic processes such as tephra fall or pyroclastic flow) involves one or more disturbance mechanisms, such as erosion, burial, heating, abrasion, and impact force (Swanson and Major, 2005; Peters et al., 2011). Primary disturbances may lead to secondary disturbances (e.g., fluvial redeposition of tephra, debris slides resulting from loss of root strength of killed trees). Both primary and secondary disturbances produce distinct geographic features, termed landscape patches or disturbance zones.
These disturbance zones are evident on remotely sensed imagery, and may be mapped and analyzed to assess spatial patterns and consequences in terms of ecosystem response and future volcanic hazards. Many of the signatures of vegetation disturbance are obvious and frequently used to characterize physical processes; other signatures are subtle and may be misinterpreted.

The 2008-2009 eruption of Chaitén Volcano provided many examples of interactions between volcanic processes and the native Valdivian rainforest that are useful in interpreting geophysical and ecological phenomena. Commencing 1 May 2008, the explosive phase of the Chaitén eruption (Major and Lara, 2013, this volume; Pallister et al., 2013, this volume) deposited tephra over northern Patagonia and triggered a small, north-directed blast that severely damaged forest on the inner caldera wall and north flank (Carn et al., 2009; Lara, 2009; Major et al., 2013, this volume). Rainfall in mid-May during a transitional phase of the eruption from explosions to effusion (Pallister et al., 2013, this volume) mobilized tephra, and the runoff left meters-thick deposits in downstream floodplain forests (Pierson et al., 2013). 
This paper focuses on geology and ecology perspectives of the 2008-2009 eruption of Chaitén. We describe effects of volcanic processes on living forest vegetation (trees, lianas, woody shrubs, and grasses (Chusquea sp. (bamboo))) and dead organic matter (e.g., killed foliage in and on the new deposits), based on field observations during the first five austral summers after the eruption began. Our observations of vegetation characteristics include structural damage, charring, mortality, and sprouting in response to damage. We use these observations to infer the disturbance mechanisms (burial, abrasion, impact force, heat, and canopy loading) involved in each disturbance type. We also note secondary disturbance processes (e.g., gully and debris slide erosion), which may alter effects of primary disturbances or create disturbance zones that extend beyond the area affected by the primary disturbances (e.g., fluvial redeposition). We also compare and contrast forest impacts of the Chaitén eruption and consequent responses with those of the intensively studied 1980 eruption of Mount St. Helens (Lipman and Mullineaux, 1981; Dale et al., 2005).

\subsection{Study area and eruption chronology and processes}

The study area, which includes the immediate vicinity of the volcano and an area extending eastward $22 \mathrm{~km}$ to Michinmahuida River (Figs. 1-4), contains a broad range of volcanic impacts. The landscape around Chaitén is characterized by very steep, glacially sculpted slopes extending from sea level to an elevation of more than $1,000 \mathrm{~m}$ and wide, flat valley floors of fluvial and glacio-fluvial outwash. Fifteen kilometers to the east, the massive Michinmahuida Volcano $(2,400 \mathrm{~m})$ is the source of rivers that skirt the north and east sides of Chaitén. Forests on some valley floor areas have been partially cleared, but hillslopes are dominated by old, northern Patagonian and Valdivian rainforest (Veblen et al., 1983; Veblen et al., 1996). The study area has a temperate climate with freezing levels generally above $1,000 \mathrm{~m}$ elevation, a modest seasonal cycle and annual mean precipitation in the 5,000-10,000 $\mathrm{mm}$ range (Garreaud et al., 2013). Annual precipitation varies by a factor of 2 to 3 from the coast to the crest of the Andes, but sparse records limit knowledge of precipitation distribution; cold spells occur year-round (Garreaud,
2009). Forest fires are an infrequent, but important non-volcanic disturbance type in the region; only rarely do fuels dry sufficiently for easy spread of fire (Holz et al., 2012).

Details of the 2008-2009 eruption chronology of Chaitén are described in Carn et al. (2009), Lara (2009), Watt et al. (2009), Alfano et al. (2011), Major and Lara (2013, this volume), and Pallister et al. (2013, this volume). We emphasize the following volcanic processes, disturbance types, and disturbance zones in our ecological studies:

- Airfall tephra was deposited in a broad sector north-east to southeast of the vent mainly in the explosive phase during the first week of the eruption (Alfano et al., 2011; Pallister et al., 2013, this volume).

- Gravel tephra ('gravel rain') fell in a narrow plume north-northeast of the vent probably on 6 May during the explosive phase of the eruption (the $\beta$ layer of Alfano et al., 2011).

- A directed blast with a strong lateral component affected portions of the inner caldera wall and flanks of the volcano, most conspicuously on the north side, during the explosive phase of the eruption (Major et al., 2013, this volume).

- Floodplain deposition occurred when flooding deposited remobilized tephra on forested floodplains of the lower Rayas and Chaitén Rivers, probably on 11-12 May 2008, when Chaitén town was inundated and as the explosive phase gave way to the transitional phase of the eruption (Pallister et al., 2013, this volume; Pierson et al., 2013).

- A pyroclastic flow triggered by partial dome collapse on 19 February 2009 (Major et al., 2013, this volume) traveled $6 \mathrm{~km}$ beyond the southern caldera rim down Caldera Creek and along the Chaitén River to within $3 \mathrm{~km}$ of Chaitén town (Fig. 1). This occurred at the end of the spine extrusion phase of the eruption (Pallister et al., 2013, this volume) and was preceded by a pyroclastic flow in the June-November 2008 period (Major et al., 2013, this volume).

- Chemical toxicity for nearby vegetation may have occurred throughout the eruption owing to gas emissions, especially of chlorine, from the initial venting and from degassing of the new dome. These emissions may have caused acid deposition on the surrounding landscape (Lowenstern et al., 2012) over an area similar to that affected by mapped tephra fall plumes (Alfano et al., 2011). 

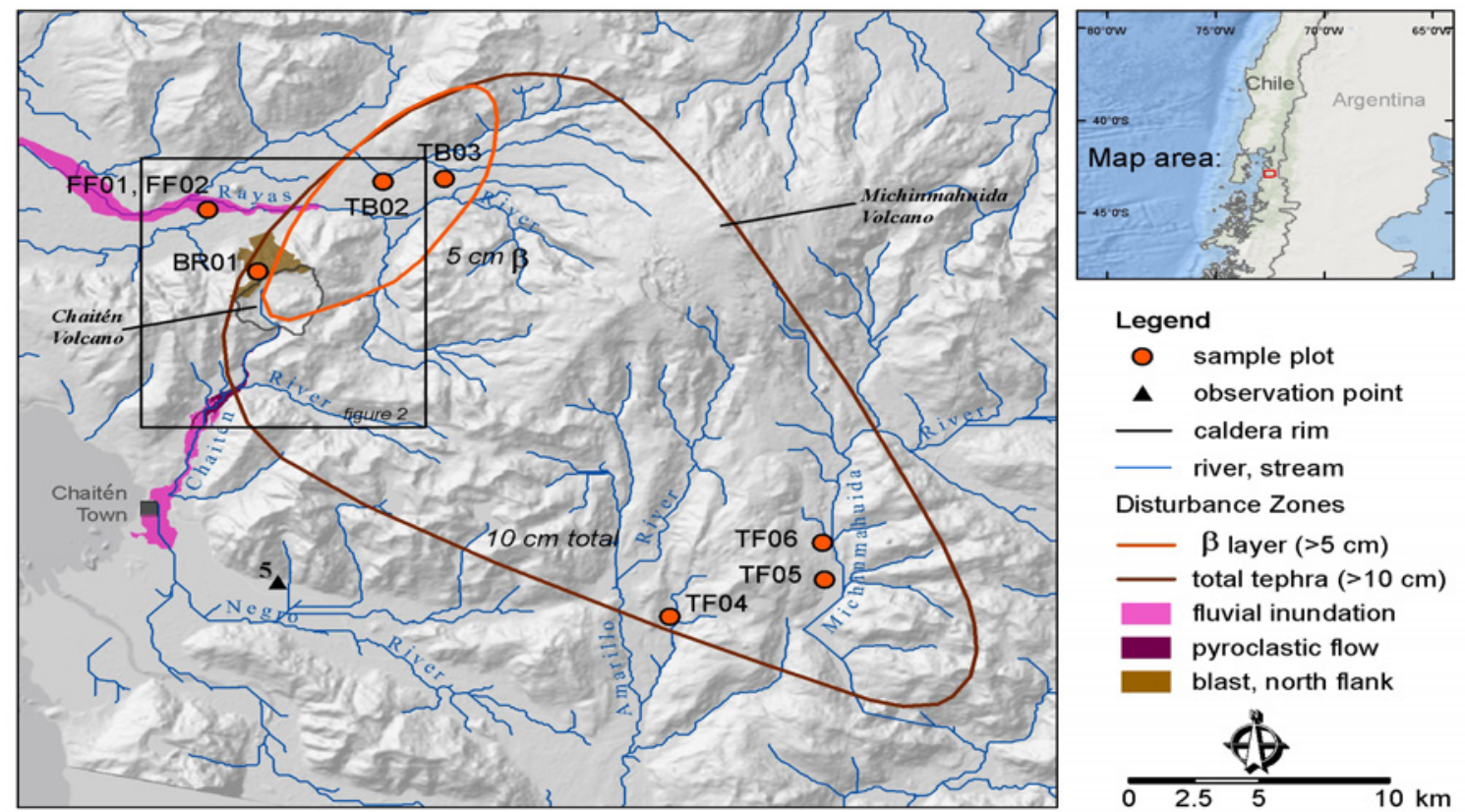

FIG. 1. Map of study area, disturbance zones, sample plots (circles), observation points (triangles), and disturbance zones within several 10s of km of Chaitén Volcano. Note that additional sample plot and observation point locations are shown on figure 2.

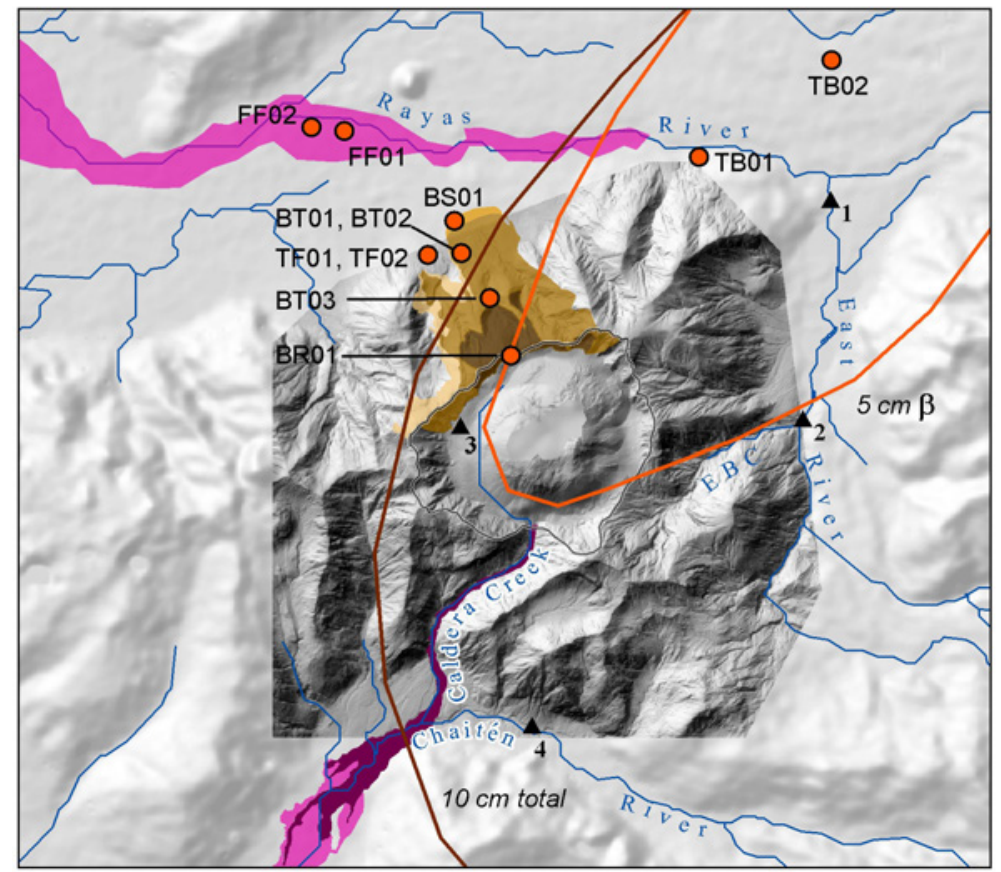

\section{Legend}

○ sample plot

A observation point

caldera rim

- river, stream

Disturbance Zones

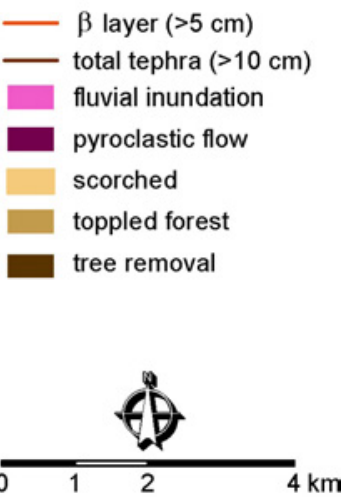

FIG. 2. Map of zones and plot (circle) and observation (triangle) locations within about $5 \mathrm{~km}$ of the volcano. The north flank blast zone delineations are from Major et al. (2013, this volume) plus a small photo-interpreted area to the north. The DEM for the central, high-resolution part of image is compiled from LIDAR surveys conducted by Digimapas Chile between 15 October and 7 December 2009 and provided by the Regional Government of Los Lagos region; see Major et al. (2013, this volume) for further details. EBC: East Breach Creek. 


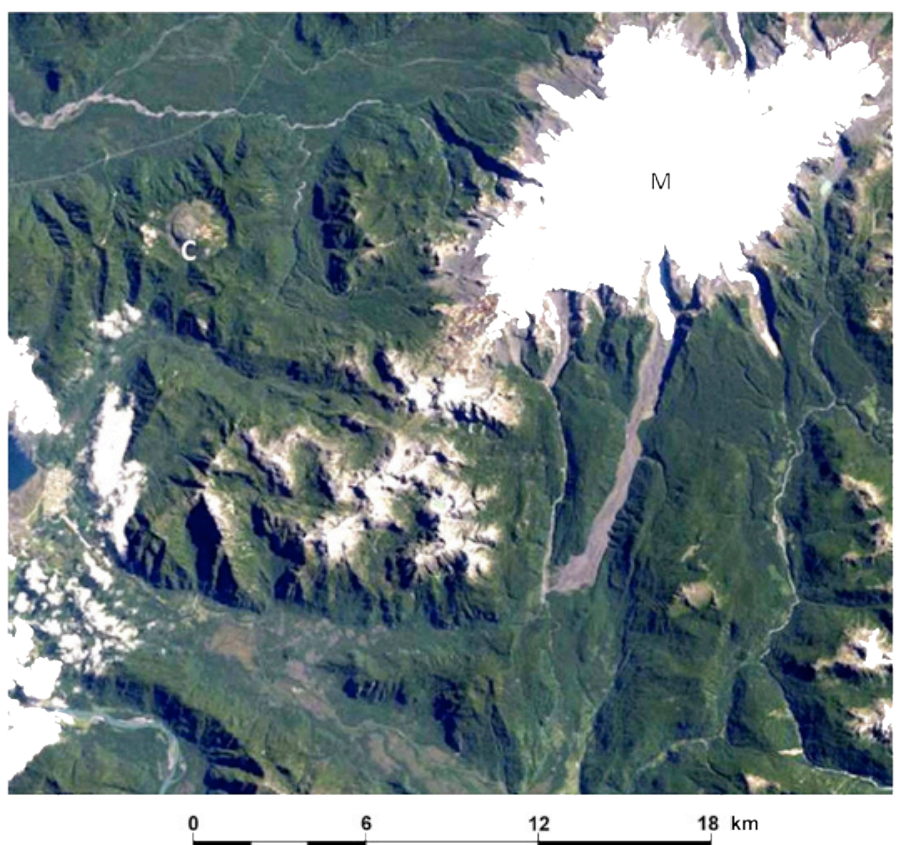

FIG. 3. True-color satellite image of Chaitén, 21 February 2000 (Source: NASA Earth Observatory, http://earthobservatory.nasa.gov/ NaturalHazards/view.php?id=19894). C: Chaitén Volcano; M: Michinmahuida Volcano.

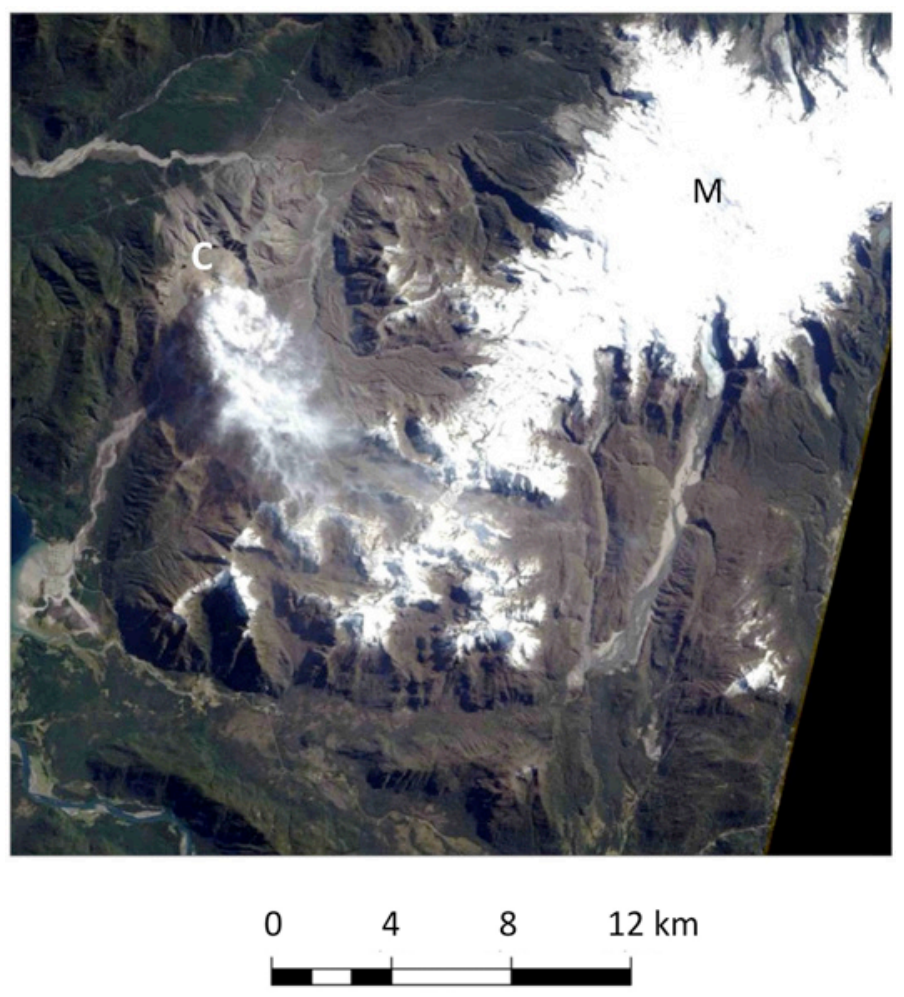

FIG. 4. True-color Satellite image of Chaitén, 30 September 2009 (Source, NASA Earth Observatory, http://earthobservatory.nasa. gov/NaturalHazards/view.php?id=40552). C: Chaitén Volcano; M: Michinmahuida Volcano. 


\section{Methods}

We conducted field sampling in austral summers of 2009 through 2013 to characterize vegetation damage in terms relevant to interpreting disturbance mechanisms of burial, heat, abrasion, impact force, and canopy loading across the areas affected by the principal volcanic and hydrologic processes (Fig. 1, Table 1). These mechanisms were interpreted from observations of volcanic and hydrologic deposits and living and dead vegetation. Thickness of burial by airfall, pyroclastic density currents (blast, pyroclastic flows), and fluvial deposits of remobilized tephra was observed in hand-dug pits and streambank exposures. Evidence of heating included (1) damage to foliage retained on trees at the margins of the blast zone (Figs. 2, 5, 6) and (2) charring of wood included within blast and pyroclastic flow deposits.
Abrasion was evident in (1) extent and depth of removal of epiphytes (including lichens and woody lianas), bark, and wood on tree trunks subjected to scour by rapid, lateral movement of rock debris and organic matter, and (2) extent of stripping of foliage, ephiphytes, and fine twigs from tree canopies and the distribution of that organic matter in tephra deposits on the ground. Impact force was inferred from (1) uprooting of trees and (2) breakage (snapping) of trunks by directed blast, pyroclastic flow, and fluvial processes. We define impact force as the combined effects of (1) the lateral forces exerted by the dynamic pressure resulting from the sustained drag of a fluid on an object (Major et al., 2013, this volume), (2) the transfer of momentum by the impulse (impact force) of the sediment-charged blast current, and (3) the domino effect of trees falling into one another. Canopy loading was recognized

\section{TABLE 1.CHARACTERISTICS OF FOREST DISTURBANCE MECHANISMS FOR DISTURBANCE TYPES OBSERVED IN THE 2008-2009 CHAITÉN ERUPTION.}

\begin{tabular}{|c|c|c|c|c|c|}
\hline $\begin{array}{c}\text { Disturbance } \\
\text { type }\end{array}$ & $\begin{array}{c}\text { Burial depth } \\
\text { (m) }\end{array}$ & Heat & Abrasion & Impact force & Canopy loading \\
\hline $\begin{array}{l}\text { Blast zone- } \\
\text { Tree removal }\end{array}$ & $\sim 1-2$ & moderate & Lateral, very high & Very high & precluded \\
\hline $\begin{array}{l}\text { Blast zone- } \\
\text { Toppled tree }\end{array}$ & $<0.1-1$ & moderate & Lateral & High & precluded \\
\hline $\begin{array}{l}\text { Blast zone- } \\
\text { Scorch }\end{array}$ & $<0.08$ & moderate & --- & --- & --- \\
\hline $\begin{array}{l}\text { Airfall tephra- } \\
\text { Gravel rain }\end{array}$ & $<0.27$ & --- & Vertical &,--- burst & precluded \\
\hline $\begin{array}{l}\text { Airfall tephra- } \\
\text { Fine tephra }\end{array}$ & $<0.5$ & --- & --- & --- & high \\
\hline $\begin{array}{l}\text { Pyroclastic } \\
\text { flow, 2/19/09 }\end{array}$ & $<6-8$ & moderate & $\begin{array}{l}\text { Lateral, very high, } \\
\text { moderate }\end{array}$ & Very high & --- \\
\hline $\begin{array}{l}\text { Fluvial } \\
\text { deposition }\end{array}$ & $\sim 1-2$ & --- & Lateral, very low & Moderate to very low & --- \\
\hline
\end{tabular}

Depth of burial varies with position within the geographic distribution of a deposit; these are values for sample plots in this study. Estimates of moderate heat $\left(50^{\circ}-200^{\circ} \mathrm{C}\right)$, based on presence of charred wood in deposit and scorching of foliage in the scorch zone (Major et al., 2013, this volume), come mainly from experiments by Moore and Sisson (1981), Winner and Casadeval (1981), and studies described in Hudspith et al. (2010). Lateral abrasion ranged in severity from very high (removal of epiphytes, bark, impact scars on the wood surface), to moderate (removal of epiphytes and some bark), to very low. Abrasion by vertical fall of gravel tephra had high severity (removal of foliage, canopy epiphytes, and twigs). Impact forces ranged from very high (trees uprooted and moved downslope); high (force sufficient to topple trees); moderate-very low (gradient of force laterally from the axis of flow to thin, tranquil flow near margins). The 'burst' notation for gravel airfall tephra refers to the lateral PDC (possible downburst) effects observed in vicinity of the Rayas River bridge on Route 7 (plot TB01, Fig. 2). Canopy loading was precluded or obscured by canopy removal in several cases, but was high (sufficient mass entrained in canopy to break branches up to $15 \mathrm{~cm}$ diameter at the point of attachment to the trunk) in tephra fall zones. '---' = not significant. Source in addition to observations in this study: Major et al. (2013, this volume). 
based on (1) tree deformation, such as bending of small, flexible branches and trees, and (2) the abundance of broken branches on the forest floor, which appeared to have broken from the weight of tephra deposited on foliage and branch systems. The weight of tephra in the canopy was perhaps exacerbated by the additional weight of precipitation.

We noted cases where the primary disturbance processes directly triggered or set the stage for secondary disturbance processes (Swanson and Major, 2005). When secondary processes occur in an area affected by a primary process, they may alter the ecological response. Debris slides are a common secondary process; these involve rapid downslope movement of soil and vegetation. Such secondary disturbances can delay ecological response by removing soil, or they can accelerate biological response, as when gully erosion removes new tephra and exposes pre-eruption soil, which may contain buried plant parts that can then sprout (Swanson and Major, 2005).

We sampled belt transects at 15 sites in austral summers of 2010-2012 to characterize forest vegetation at the time of the eruption, impacts of eruption processes on vegetation, and initial sprouting response of vegetation (Table 2). At three sites (BT01, BT02, TB01, Fig. 2), transects were sampled in 2010 and resampled in 2012 to assess changes in sprouting from trees. Transects were $100 \mathrm{~m}$ by $12 \mathrm{~m}$, oriented parallel to contour. In some locations pre-eruption forest disturbance or site access limited transect size and properties sampled. For example, in some areas near the crater rim, no live or standing trees were left, and slopes were steep and gullied. Therefore, we noted the absence of standing trees and sampled downed wood along one $50 \mathrm{-m}$ transect $30 \mathrm{~m}$ below the rim and a second $50-\mathrm{m}$ transect $60 \mathrm{~m}$ below the rim. The narrowness of the scorch zone along the distal margin of the blast zone (Fig. 5) limited the transect in that zone to 75 by $6 \mathrm{~m}$. In each transect, we tallied all trees $>5 \mathrm{~cm}$ diameter at breast height (DBH) and recorded species, location, DBH (here after 'diameter'), and condition. Tree conditions included live, dead at the time of the eruption, recently killed (probably by the eruption), and standing vs. toppled, which could be uprooted, broken, or leaning. For live trees, we noted the extent and location of dead, broken or missing branches, and the location and vigor of sprouting. Tree species with foliage were identified following Donoso and Ramírez (1994) and Donoso (2008). Along the centerline of each transect we tallied the location and largest diameter of branches ('branch fall') or trunks ('toppled trees') lying on the ground. We assessed whether branches and trunks fell in the time frame of the eruption, based on freshness of breakage and depth of burial by tephra. As time passed after the eruption, it became more challenging to distinguish branch fall caused by canopy loading from the gradual shedding of branches from dead and dying trees.

In general we described tephra stratigraphy in terms of thickness, texture, color, and type of material at 25-m intervals along the centerline of each transect. We observed texture to confirm the interpretations of disturbance mechanisms (for example, whether deposits were coarse enough to abrade vegetation). We interpreted stratigraphy of the deposits to distinguish multiple events and their sequencing. At some sites we dissected the tephra deposits in 5-cm-depth increments, and for each increment we noted and photographed abundance and type of organic matter (e.g., leaves (to species), twigs, canopy lichen fragments). In contrast to Alfano et al. (2011), we commonly sampled tephra stratigraphy under forest cover, in part because we wished to assess influences of tephra on the canopy and the timing of litter fall relative to tephra fall. Presence of forest cover can disrupt stratigraphy by temporarily retaining tephra and then delivering it to the ground over time as leaves fall or wind and rain shake tephra out of the canopy. Also, under forest cover organic matter may be incorporated in the deposits; this is of interest in studies of canopydisturbance interactions, but it is an undesirable complication for standard tephra stratigraphy studies (e.g., Alfano et al., 2011).

Transect-based sampling was supplemented by semi-quantitative observations of vegetation conditions and measures of volcanic disturbance at 36 additional sites distributed across the major disturbance zones. We made reconnaissance observations of tephra stratigraphy and vegetation damage at an even larger suite of sites distributed across accessible areas.

We mapped disturbance zones using (1) observations from field sampling, (2) interpretations of remote sensing images, (3) interpretation of tephra fall distribution by Alfano et al. (2011), which we supplemented with our field observations of tephra profiles, and (4) observations from other studies 
TABLE 2. FOREST CHARACTERISTICS IN TREE TRANSECTS AT PLOTS SAMPLED AT CHAITÉN IN JANUARY 2010,2011, AND 2012.

\begin{tabular}{|c|c|c|c|c|c|c|c|c|c|c|c|c|c|c|c|}
\hline Code & $\begin{array}{r}\text { Area } \\
\text { (ha) }\end{array}$ & $\begin{array}{c}\text { Stems } \\
\text { ha }^{-1}\end{array}$ & $\begin{array}{c}\text { Mean } \\
\text { diameter } \\
(\mathrm{cm})\end{array}$ & $\begin{array}{c}\text { Basal } \\
\text { area } \\
\left(\mathrm{m}^{2}\right)\end{array}$ & $\begin{array}{c}\% \\
\text { live }\end{array}$ & $\begin{array}{c}\% \\
\text { dead }\end{array}$ & $\begin{array}{c}\% \\
\text { killed }\end{array}$ & $\begin{array}{c}\% \text { spr } \\
\text { twig }\end{array}$ & $\begin{array}{c}\% \text { spr } \\
\text { branches }\end{array}$ & $\begin{array}{l}\% \text { spr } \\
\text { trunks }\end{array}$ & $\begin{array}{c}\% \text { spr } \\
\text { rootwad }\end{array}$ & $\begin{array}{c}\% \\
\text { not } \\
\text { spr }\end{array}$ & $\begin{array}{c}\% \\
\text { broken } \\
\text { stems }\end{array}$ & $\begin{array}{l}\% \text { up- } \\
\text { rooted }\end{array}$ & Date \\
\hline \multicolumn{16}{|c|}{ Blast zone-tree removal } \\
\hline BR01 & -- & -- & -- & -- & 0 & -- & 100 & -- & -- & 0 & -- & 100 & -- & -- & 2010 \\
\hline \multicolumn{16}{|c|}{ Blast zone-toppled tree } \\
\hline ВТ03 & 0.09 & 344 & 38 & 57 & 3 & 6 & 91 & -- & -- & 6 & -- & 94 & 0 & 91 & 2010 \\
\hline BT02 & 0.06 & 483 & 34 & 64 & 14 & 0 & 86 & -- & -- & 19 & -- & 81 & 17 & 76 & 2010 \\
\hline BT02 & 0.12 & 417 & 34 & 69 & 10 & 4 & 80 & 0 & 0 & 4 & 14 & 86 & 14 & 74 & 2012 \\
\hline BT01 & 0.06 & 400 & 43 & 124 & 25 & 4 & 71 & -- & -- & 34 & -- & 66 & 13 & 71 & 2010 \\
\hline BT01 & 0.12 & 450 & 43 & 149 & 11 & 4 & 83 & 0 & 0 & 13 & 6 & 85 & 22 & 72 & 2012 \\
\hline \multicolumn{16}{|c|}{ Blast zone-scorch } \\
\hline BS01 & 0.045 & 756 & 25 & 58 & 71 & 6 & 24 & -- & -- & 53 & -- & 47 & 0 & 0 & 2010 \\
\hline \multicolumn{16}{|c|}{ Airfall tephra-gravel rain } \\
\hline TB01 & 0.135 & 259 & 51 & 86 & 74 & 6 & 20 & -- & -- & 74 & -- & 26 & 0 & 11 & 2010 \\
\hline TB01 & 0.24 & 225 & 46 & 70 & 50 & 6 & 44 & -- & -- & 50 & -- & 50 & 6 & -- & 2012 \\
\hline TB02 & 0.12 & 2,367 & 16 & 73 & 52 & 12 & 35 & 27 & 10 & 48 & -- & 51 & 1 & 0 & 2012 \\
\hline TB03 & 0.12 & 2,225 & 15 & 63 & 74 & 12 & 13 & 55 & 22 & 39 & -- & 26 & 1 & 0 & 2012 \\
\hline \multicolumn{16}{|c|}{ Airfall tephra-fine tephra } \\
\hline TF01 & 0.09 & 567 & 33 & 80 & 100 & 0 & 0 & 100 & -- & -- & -- & 0 & 0 & 0 & 2010 \\
\hline TF02 & 0.09 & 422 & 48 & 152 & 97 & 3 & 0 & 97 & -- & -- & -- & 0 & 0 & 0 & 2010 \\
\hline TF04 & 0.09 & 3,356 & 11 & 71 & 93 & 5 & 2 & 100 & 1 & 49 & -- & 0 & 6 & 0 & 2011 \\
\hline TF05 & 0.12 & 425 & 41 & 89 & 80 & 10 & 10 & -- & 27 & -- & -- & 73 & 27 & 0 & 2010 \\
\hline TF06 & 0.09 & 544 & 23 & 48 & 82 & 10 & 8 & 35 & 27 & 61 & -- & 20 & 51 & 0 & 2012 \\
\hline \multicolumn{16}{|c|}{ Floodplain-fluvial deposition } \\
\hline FF01 & 0.12 & 2,092 & 16 & 82 & 43 & 7 & 50 & 37 & 22 & 6 & & 58 & 6 & 0 & 2012 \\
\hline FF02 & 0.12 & 2,558 & 15 & 76 & 6 & 11 & 82 & 6 & 0 & 1 & & 93 & 2 & 0 & 2012 \\
\hline
\end{tabular}

'\% spr' = percent of trees sprouting. In plots in which we did not differentiate sprouting by position on the tree, the '\% spr trunk' column provides the percent of trees that were sprouting at any position on the tree. '--' = no observations were made because no material was present to express the phenomenon. 
(e.g., Major et al., 2013, this volume, Fig. 4). Areas of each disturbance zone (e.g., tephra fall, floodplain inundation, directed blast) were computed using geographic information system software (Arcinfo v. 10.1) applied to a digital terrain basemap, tephra-fall maps from Alfano et al. (2011), and satellite images (for example, Fig. 4).

Sampling of disturbed vegetation was limited by several factors. In some cases several volcanic processes affected the same area, compounding the impacts, producing overlapping deposits, and complicating interpretation of impacts on vegetation. Limited field access precluded observations in some key areas. Unsampled areas include high elevation sites in remote areas, areas of very thin deposits, and areas of very thick tephra deposits east of the volcano in the upper reaches of the Chaitén and Rayas River basins. We also observed substantial heterogeneity of forest conditions, only some of which were accessible. Although the field plots are small in size and number, we believe they are broadly representative of affected forest.

\section{Results}

\subsection{Map of disturbance zones}

These observations form the basis for a map of volcanogenic disturbance zones within $30 \mathrm{~km}$ of Chaitén Volcano (Figs. 1, 2, 5, 6). By far the largest zone affected by volcanic disturbances was the airfall tephra zone, followed by much smaller areas of floodplain deposition and directed blast (Figs. 1, 2). The airfall tephra zone included three distinctive sub-areas: a zone of thick $(>5 \mathrm{~cm})$, coarse tephra (approximately $50 \mathrm{~km}^{2}$ ), hereafter referred as 'gravel rain'; a zone of thick $(>10 \mathrm{~cm})$, fine-grained tephra $\left(480 \mathrm{~km}^{2}\right)$; and a zone of thin $(<10 \mathrm{~cm})$, fine-grained tephra (approximately $40,000 \mathrm{~km}^{2}$ ). Complex wind patterns carried dominantly silt- to sand-sized tephra in a broad arc northeast to southeast of Chaitén into Argentina and beyond (Carn et al., 2009; Alfano et al., 2011). Smaller areas were affected by a directed blast or processes leading to burial of floodplain forest. The $4-\mathrm{km}^{2}$ area of the directed blast affecting the inner caldera wall and north-northwest flank included $0.8 \mathrm{~km}^{2}$ in treeremoval area, $2.5 \mathrm{~km}^{2}$ in toppled forest, and $0.7 \mathrm{~km}^{2}$ in scorched forest (Fig. 2). Fluvial deposition inundated $5 \mathrm{~km}^{2}$ of forested floodplain in the Rayas River valley and a few $\mathrm{km}^{2}$ in the Chaitén River valley. The pyroclastic flow that occurred in February 2009 inundated approximately $1.5 \mathrm{~km}^{2}$ of the Chaitén River valley floor (Major et al., 2013, this volume), imposing further damage to forests that had already been disturbed by fluvial deposition.

Each disturbance zone is defined by the type of disturbance process and in some cases by its conspicuous ecological disturbance signature (Table 1). For each disturbance type and zone we describe characteristics of the affected forest, geophysical processes that affected the zone, initial effects on vegetation, and the extent of the mapped zone (Table 1). Some parts of the landscape experienced several geophysical processes. In general the most severe disturbance events were the least extensive.

\subsection{Characteristics of affected vegetation}

Size and species of individual trees and their stand context can affect their susceptibility to various types of disturbance. Forests in the different disturbance zones varied in the size, stem density, and species of trees (Table 2).

Most stands around Chaitén are native, oldgrowth forests containing some trees with diameters exceeding one meter and probably several centuries in age; hereafter we refer to them simply as old trees or old forest. Among these stands, stem density ranges from 250 to 550 stems ha $^{-1}$ and basal area $\left(\mathrm{m}^{2}\right.$ of stem cross-sectional area of trunks at breast height per hectare) ranges from 48 to $124 \mathrm{~m}^{2} \mathrm{ha}^{-1}$, although there is some uncertainty about basal area estimates, given damage and burial of relict trees in some disturbance zones. In these old stands, a few species dominate the largest size classes: Eucryphia cordifolia, Laureliopsis phillippiana, Nothofagus dombeyi (or N. nitida), and Weinmannia trichosperma. Some selective logging of larger trees occurred prior to the eruption in some of the older stands.

Dense, small-diameter, young stands of low species diversity occur in several sampled sites. Along the Rayas River young forest occurred on recent floodplain surfaces. Elsewhere, young forest may have been the result of past clearing and burning for pasture or forestry. In these young stands stem density ranges from 2,100 to 2,600 stems ha $^{-1}$; basal area ranges from 63 to $83 \mathrm{~m}^{2} \mathrm{ha}^{-1}$; and common tree species include Amomyrtus meli, A. luma, Drimys winteri, Nothofagus dombeyi (or N. nitida), Tepualia stipularis, and Weinmannia trichosperma. 


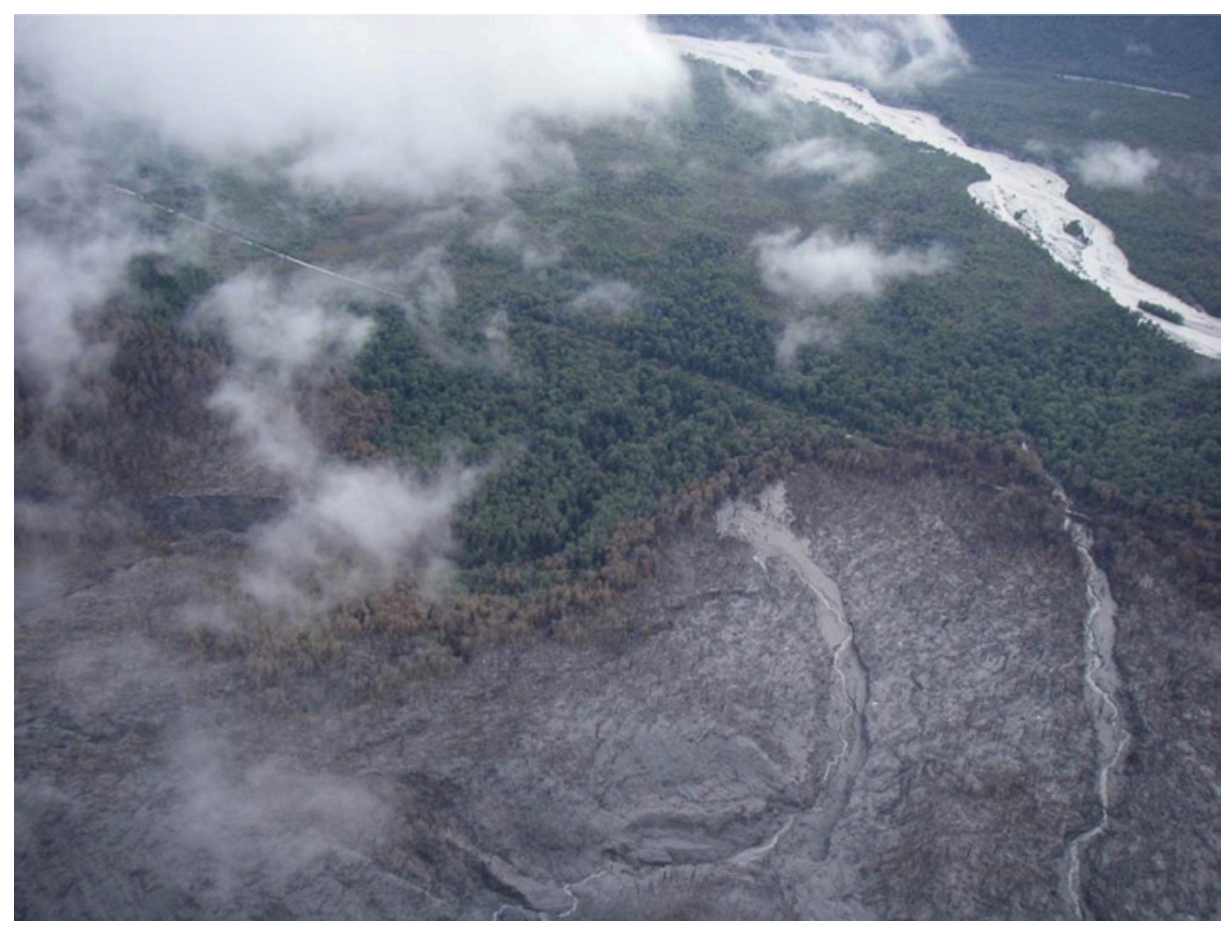

FIG. 5. Oblique aerial view of north flank with toppled-tree and scorch zones in foreground and Rayas River in upper right, looking to the northwest. This 6 June 2008 view shows the narrow scorch zone with foliage (brown) still on the trees between the toppled-tree zone (lower part of photo) and living forest (green trees in upper part of photo) (photo: A. Lockhart, USGS).

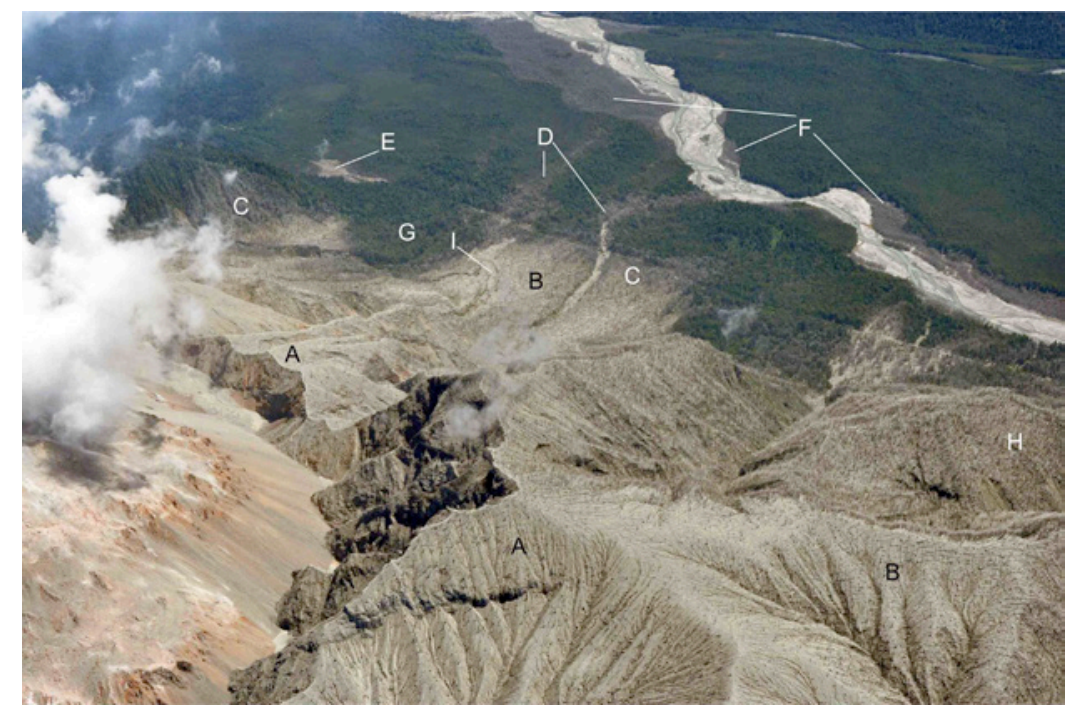

FIG. 6. Oblique aerial view of north flank in January 2010 with the new dome in lower left and Rayas River in upper right, looking to the northwest. Types of deposits and forest disturbance zone on the north flank resulting from the 2008-2009 Chaitén eruption. Tree removal (A); toppled trees (B); scorch zone (C); and fluvial deposition in riparian zones of streams flowing from the blast zone (D), wetlands (E), and Rayas River floodplain (F); tephra fall (thin (5-10 cm), sandy tephra) in living forest (G); thick $(15-50 \mathrm{~cm})$, gravelly tephra in severely damaged forest $(\mathbf{H})$; and syn- or post-eruption debris flow deposit in stream channel (I). Route 7 highway passes from upper left to right center. (Photo: J. Pallister, USGS. Source: Pallister et al., 2010). 


\subsection{Blast zone: physical processes and forest conditions}

\subsubsection{Volcanic processes in the blast zone}

In their discussion of pyroclastic density currents (PDCs) associated with the 2008-2009 Chaitén eruption, Major et al. (2013, this volume) describe the event on the north flank as having the characteristics of a directed blast (hereafter we refer to it as the 'blast'). Although PDCs affected other areas around the volcano (Major et al., 2013, this volume), we focus on the north flank event because it affected an area of old forest, it is largely surrounded by relatively undisturbed, old forest, and subsequent volcanic processes have not obscured the effects of this blast. A common signature of a directed blast into forest is a gradient of damage decreasing in the down-blast direction from a tree-removal zone close to the blast source, transitioning into a zone of toppled forest leading to a fringe of standing trees with scorched foliage still retained in the canopy. This type of damage gradient produced by PDCs has been observed, for example, at Mount St. Helens (Lipman and Mullineaux, 1981, Plate 1) and Merapi (Kelfoun et al., 2000). The bulk density of a PDC, the size of the largest rock and wood fragments, and velocity of the PDC all decrease with distance from the vent. As the most dense and largest particles drop out of a PDC and as it encounters frictional resistance of standing forest and decreasing slope gradient, the velocity and force of a PDC are reduced, producing this gradient of disturbance. The boundary between the blast-affected and unaffected forest is commonly sharp, and the zone of scorching may actually climb into the forest canopy as the distal end of the current experiences buoyant lift (Andrews and Manga, 2011) or encounters denser, cool air on a valley floor (Fig. 5). Individual trees in the Chaitén blast zone experienced asymmetrical abrasion on trunks, removal of branches, and directional toppling and snapping of trunks as a result of impact force (Major et al., 2013, this volume).

\subsubsection{Spatial pattern of volcanic processes in the blast zone}

The north-flank blast at Chaitén covered $4 \mathrm{~km}^{2}$ including the inner caldera wall and a swath of damaged forest downslope to the north; this blast zone is bordered by live forest along the west and north sides (Figs. 2, 5). Although the eastern boundary of the scorch zone is less distinct because the forest was damaged by deposition of gravel tephra (the $\beta$ layer of Alfano et al., 2011), the eastern boundary of the toppled-tree zone is clear where it meets standing dead trees along the base of a north-trending ridge. Our estimate of $0.7 \mathrm{~km}^{2}$ of scorched forest is a minimum because of its erasure by gravel rain on the east side of the blast zone. Less distinctive and extensive areas with blast-like features (e.g., toppled trees pointing away from the vent) extend to the west and east from the caldera rim (Fig. 6; Major et al., 2013, this volume), but we have not visited these sites to confirm interpretations. We did, however, discover patches of several to dozens of directionally toppled trees in the vicinity of the Rayas River bridge, with multiple additional features indicating lateral impact by a current that did not originate at the vent (see gravel rain section, below).

\subsubsection{Tree removal zone}

Spatial patterns of tree damage within the $0.8 \mathrm{~km}^{2}$ tree-removal part of the blast zone on the north flank of Chaitén are quite heterogeneous and lacking in sharp boundaries. Slight variation in slope gradient is accompanied by abrupt change from clear evidence of tree removal (e.g., 40-cm diameter trees sheared off $60 \mathrm{~cm}$ above the ground and no evidence of the upper part of the tree) to patches of small-diameter toppled trees left in place where the slope becomes a few degrees steeper and provides some topographic shelter. The tree-removal zone starts at the caldera rim and grades laterally along the rim into toppled and then standing dead trees both to the northeast and the southwest. Downslope the tree-removal zone grades into the toppled-tree zone, which is marked by numerous syn- or post-eruption debris slides on very steep slopes within 200-700 m of the rim. This area of numerous slides results from the combined influences of tree toppling and steep $\left(>35^{\circ}\right)$ slopes where heads of streams flowing to the north are deeply incised. Much of the actual tree-removal zone is higher on the slope where drainages are not deeply cut.

Tephra deposits in the tree removal zone are poorly sorted, weakly stratified gravel, containing lithic clasts up to $30 \mathrm{~cm}$. These deposits exceed $1.5 \mathrm{~m}$ in thickness in some areas along the rim, and gullies cut into the deposits $50 \mathrm{~m}$ downslope of the rim exposed pre-eruption soil beneath approximately $60 \mathrm{~cm}$ of blast deposits overlain by $10 \mathrm{~cm}$ of coarse sand to fine gravel air 
fall tephra (Fig. 7; see Major et al. (2013, this volume) for further description). Pieces of wood were commonly deeply charred if they were buried in the poorly sorted, gravelly blast deposit within $100 \mathrm{~m}$ of the rim, but wood that was exposed above the deposits was not charred. Some wood fragments entrained in the blast deposits were not charred, perhaps because 'green' wood was too wet to char, but wood that was dead and dry at the time of the eruption was susceptible to charring. Fine organic matter (leaves, twigs, branches) appears to have been entrained in the blast current and incorporated in the deposits downslope. Major et al. (2013, this volume) draw on observations at Chaitén and findings at other volcanoes (Moore and Sisson, 1981; Winner and Casadevall, 1981; Voight and Davis, 2000) to conclude that blast current temperature was probably in the range of $50^{\circ}-200^{\circ} \mathrm{C}$.

Observations of vegetation in the tree-removal zone indicate that the force of the blast at the caldera rim was sufficient to topple and abrade trees, including removing large branches, and in some cases to shear off trees. Several large trunks were sheared off close to the ground and the upper part of the tree was completely removed. Portions of both toppled and standing tree trunks remained close to the rim, and a single remnant old tree remained rooted right at the rim (Fig. 7). Several large, fallen trees pointing down slope may have been transported a short distance (tens of meters), but their rooting sites were obscured by the $>1 \mathrm{~m}$ of blast deposit. Blast and airfall tephra deposits plastered against the vent-facing side of the root masses indicate that toppling occurred early in the event. A large, standing dead tree within a few tens of meters of the rim (Fig. 7) was deeply abraded on the vent-facing side. Numerous stems of small remaining trees are tipped downslope, but are not parallel with the slope (Fig. 7), suggesting that they are still partially rooted in soil beneath the mantle of blast tephra. The trunks of these small trees have been scoured to bare wood on their vent-facing

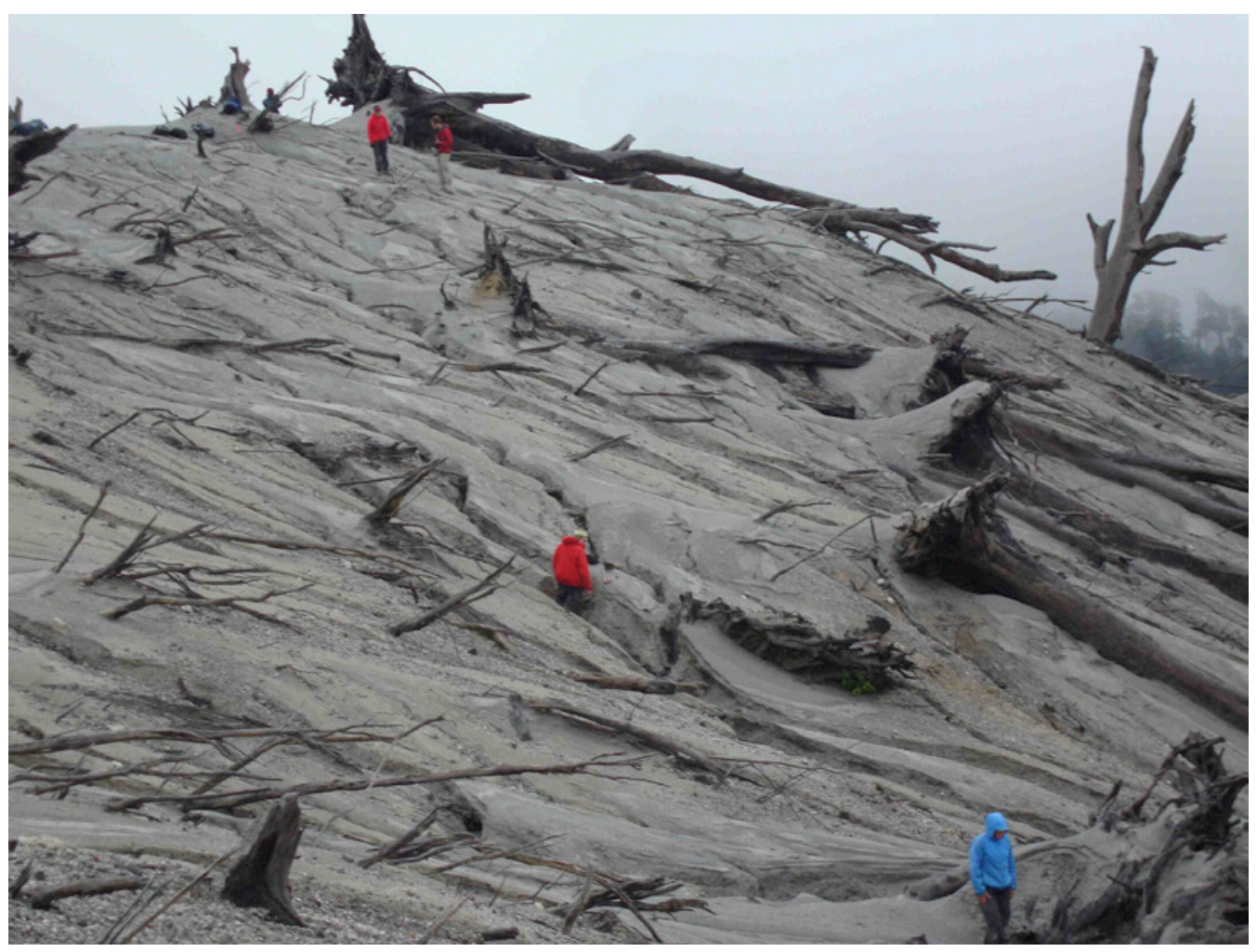

FIG. 7. Blast zone, tree-removal area. Upper north flank showing damage to large and small trees. Caldera rim is at top left. (Photo: F. Swanson, January 2011). 
side and the wood is pitted by impacts of rocks transported by the blast current.

Stand-level vegetation measurements in the tree removal zone indicate that forest cover on the north rim at the time of the eruption was composed of scattered large, old Nothofagus trees with lower stem density than farther downslope plus an extensive cover of understory trees (Fig. 7, Table 3). A plot sampled in January 2010 near the caldera rim (BR01, upper left of Fig. 7) was dominated by small pieces of wood (mean diameter $=9.3 \mathrm{~cm}$ ). These were either small, understory trees tipped over, but not removed by the blast, or small wood pieces entrained in the blast deposits and then exposed by gully erosion of the new deposits (Fig. 7). No upright stems and no live vegetation were observed in the plot. The woody organic matter near the rim remains as a legacy from the pre-eruption forest and is likely to contribute to post-eruption soil development.

Secondary disturbances in the tree-removal zone occurred during storms after the eruption began, when runoff cut gullies more than $1 \mathrm{~m}$ deep into the new blast and airfall tephra deposits and preeruption soil in the tree-removal zone (Fig. 7). The low infiltration capacity of the fine tephra covering the slopes and the paucity of organic matter to intercept rain and interrupt overland flow may have contributed to gully formation, as observed at Mount St. Helens (Swanson et al., 1983). By January 2013, gully and surface erosion of tephra was

TABLE 3. SUMMARY OF BRANCHES AND TRUNKS ON THE GROUND SURFACE PER 100 M OF TRANSECT IN PLOTS SAMPLED AT CHAITÉN IN JANUARY 2010, 2011 AND 2012.

\begin{tabular}{|c|c|c|c|c|c|c|}
\hline code & $\begin{array}{c}\text { Transect } \\
\text { length }(m)\end{array}$ & $\begin{array}{l}\text { Branches } \\
\text { per } 100 \mathrm{~m}\end{array}$ & $\begin{array}{c}\text { average } \\
\text { diameter } \\
(\mathrm{cm})\end{array}$ & Boles $/ 100 m$ & $\begin{array}{c}\text { average } \\
\text { diameter } \\
(\mathrm{cm})\end{array}$ & Date \\
\hline \multicolumn{7}{|c|}{ Blast zone-tree removal } \\
\hline BR01 & 100 & -- & -- & 69 & 9.3 & 2010 \\
\hline \multicolumn{7}{|c|}{ Blast zone-toppled tree } \\
\hline ВT03 & 100 & -- & -- & 214 & 9.8 & 2010 \\
\hline BT02 & 100 & -- & -- & 65 & 45.1 & 2012 \\
\hline BT01 & 100 & -- & -- & 63 & 43.7 & 2012 \\
\hline \multicolumn{7}{|c|}{ Blast zone-scorch } \\
\hline BS01 & 75 & 13 & 5.5 & -- & -- & 2010 \\
\hline \multicolumn{7}{|c|}{ Airfall tephra-gravel rain } \\
\hline TB01 & 100 & 9 & 9.0 & -- & -- & 2010 \\
\hline TB02 & 100 & 20 & 2.7 & -- & -- & 2012 \\
\hline TB03 & 50 & 91 & 2.5 & -- & -- & 2012 \\
\hline \multicolumn{7}{|c|}{ Airfall tephra-fine tephra } \\
\hline TF04* & 75 & 23 & 3.7 & -- & -- & 2011 \\
\hline TF05 & 100 & 44 & 11.5 & -- & -- & 2010 \\
\hline TF06 & 60 & 105 & 8.0 & -- & -- & 2012 \\
\hline TF01 & 75 & 1 & 7.0 & -- & -- & 2010 \\
\hline TF02 & 75 & 9 & 7.4 & -- & -- & 2010 \\
\hline \multicolumn{7}{|c|}{ Floodplain-fluvial deposition } \\
\hline FF01* & 100 & 37 & 3.4 & -- & -- & 2012 \\
\hline $\mathrm{FF} 02 *$ & 100 & 111 & 2.7 & -- & -- & 2012 \\
\hline
\end{tabular}

At most sites, numbers indicate branches that were snapped by canopy loading during the eruption, but ' $*$ ' indicates sites of more recent observations and minimal airfall tephra where the dominant source of branches is gradual shedding of branches from dead trees. '--' = no observations were made because no material was present, or fallen branches could not be accurately discriminated from other tree parts in the blast zone. 
rather extensive beyond $50 \mathrm{~m}$ downslope from the rim, and sprouting of plants from the post-eruption soil was common.

\subsubsection{Toppled-tree zone}

Spatial patterns of tree damage in the $2.5 \mathrm{~km}^{2}$ toppled-tree part of the blast zone vary in response to topographic exposure and generally declining impact force down the blast-current flowpath. Structural damage declined, and the numbers of standing broken trunks and the amount of sprouting increased downslope. Some of this gradient is attributable to the increasing density of large trees in lower slope positions (Table 2, 3). Especially in dense stands on the lower slopes, the complex branch structure of larger trees may have contributed to a 'domino effect' in which falling trees knocked down trees they fell onto, a process that contributed to a great deal of branch breakage. Trees leveled by the blast within the toppled-tree zone remained in place, as indicated by the juxtaposition of root wads and pits, but fine organic matter (e.g., leaves and twigs) was abraded from the toppled trees and thoroughly mixed within the blast current and the resulting deposit.

The blast deposit in the toppled-tree zone was poorly sorted sand to gravel with thickness ranging from a few cm to many decimeters. Deposit-thickness variability was accentuated by the complex microtopography created by fallen trees, up-turned root wads, and root pits. Most organic matter included in the blast deposit was not charred; the few charred pieces we observed were buried in blast deposit $>50$ $\mathrm{cm}$ thick, which may have retained heat sufficient to induce charring. Major et al. (2013, this volume) estimate a blast temperature in the range $50^{\circ}-200^{\circ} \mathrm{C}$ for the toppled-tree zone, and they provide a more detailed description of tephra stratigraphy and abrasion damage.

The impact force of the blast on the north flank toppled many trees and sheared off others, leaving many tree trunks 10-15 $\mathrm{m}$ tall (Fig. 8). In the steeper, complex topography of the upper part of the toppledtree zone, sheared-off tree trunks occurred in patches in the lee of sheltering topographic features. Farther downslope, the sheared-off tree trunks were widely dispersed among the toppled trees. In the upper and middle sections of the toppled-tree zone, the blast current stripped twigs and branches from the trees. The blast-facing sides of upright and fallen trees were substantially abraded; lianas and bark had been stripped from the trunks, and rock fragments as large as $10 \mathrm{~cm}$ were lodged in tree trunks as high as $8 \mathrm{~m}$ above ground level (e.g., near plot location BT01) (see Fig. 6 in Major et al., 2013, this volume). In the first few years after the eruption, several species of trees (e.g., Weinmannia, Eucryphia) exhibited sprouting from standing, broken trunks; from the sides of the fallen trunks; and from the top, side, and underside of up-turned rootwads. This sprouting indicated that heating was not intense enough to kill buds protected under the bark on large trunks. However, many sprouts had died by the fourth growing season after the eruption.

Stand-level observations indicated that prior to the eruption, the toppled-tree zone was an old forest, dominated by large trees of Eucryphia, Weinmannia, $N$. dombeyi, N. nítida, Laureliopsis, Drimys winteri, small Amomyrtus luma and A. meli, and other species not identifiable because of toppling and stripping of foliage. The pre-eruption forest had 350 to $500 \mathrm{stems}$ ha $^{-1}$ with a mean diameter of 34 to $43 \mathrm{~cm}$, and a basal area of 57 to $149 \mathrm{~m}^{2} \mathrm{ha}^{-1}$ (Table 2). Systematic inventory of trees within the plots indicated that Weinmannia, Eucryphia, and Amomyrtus spp. had sprouted, but Laureliopsis and Nothofagus species had not. The proportion of uprooted trees (as distinguished from broken) varied from $91 \%$ on steep mid-slope positions, to $76 \%$ and $71 \%$ on the lower slope positions of the blast area (Table 2). Consistent with the gradient of disturbance away from the crater rim, in January 2010 the proportion of stems in the toppled-tree zone that were sprouting increased from $6 \%$ on the steep, mid-slope position to $19 \%$ on the upper portion of the lower slope, to $34 \%$ in the lower portion of the lower slope (Table 2). Consistent with observations of sprout mortality in repeated observations of individual tagged trees, by January 2012 (3.5 years after the eruption) sprouting of toppled trees on the lower slopes of the blast area had declined from $34 \%$ to only $20 \%$ of stems (Table 2). In 2010, in plots BT01 and BT02 (Fig. 2), 31 large-diameter, fallen Weinmannia trees had an average of 2.8 sprouts per tree on root wads and 3.5 on lower trunk positions. By January 2012, $37 \%$ of sprouts on trunks were dead, but only $5 \%$ of sprouts on rootwads were dead, indicating that rootwads provided better habitat in terms of access to soil water and nutrient resources.

Wood decomposition has been impressively rapid in the toppled-tree zone. Abundant sporocarps 


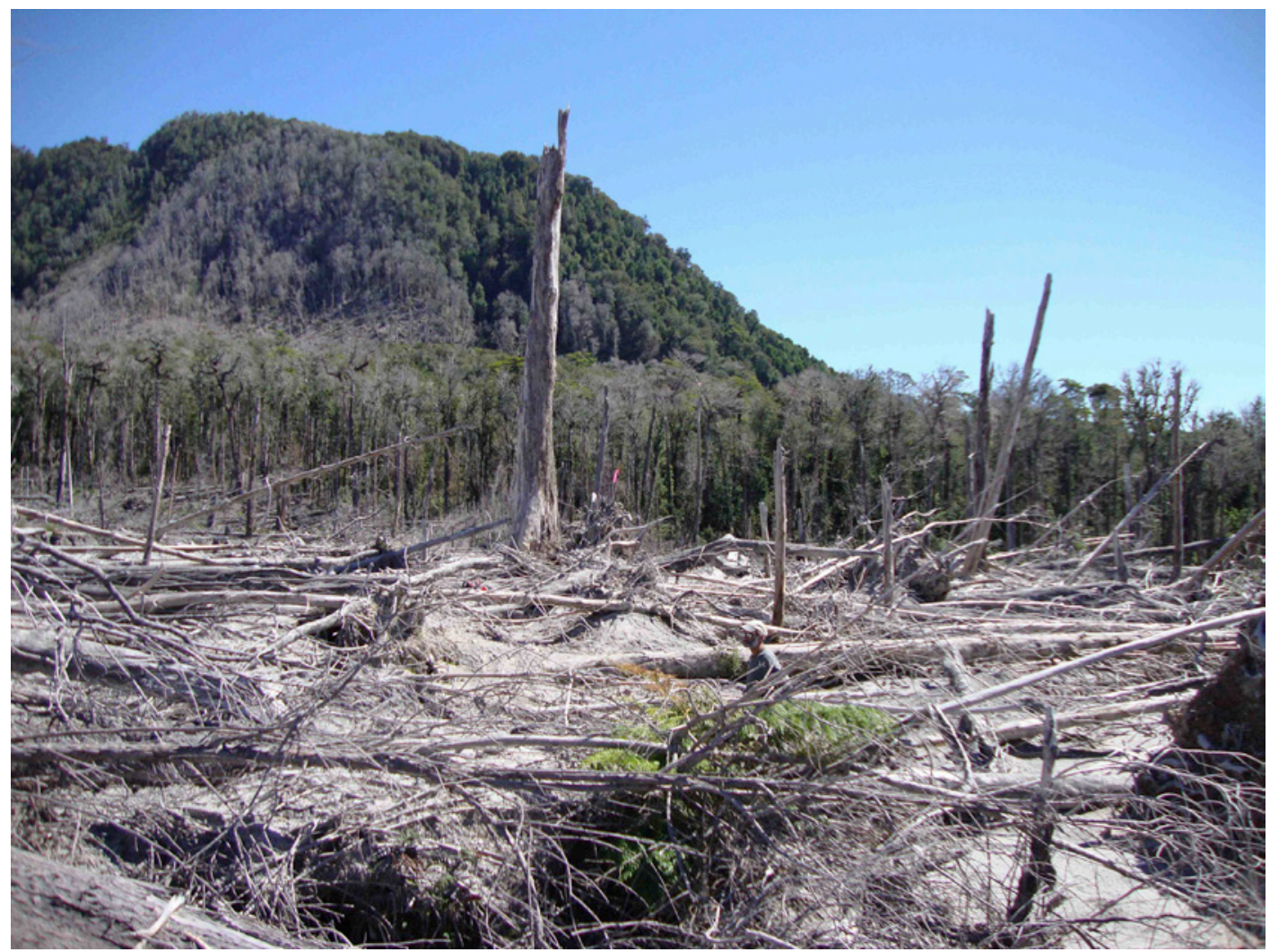

FIG. 8. View to west on the north flank of Chaitén across the toppled-tree zone in the foreground to a narrow strip of scorch zone next to live forest in middle distance. A patch of scorched forest is on far hillside (upper left) where the blast current ran upslope. Direction of blast is left to right. Note person in right center. (Photo: J. Jones, January 2010, near plot BT01).

of wood-decomposing fungi were observed in 2010 and 2011. These fungal fruiting bodies imply an abundant supply of wood within the blast deposit or at the interface of the new deposits and pre-eruption soil. By 2013, sporocarps were less abundant, probably because readily decomposed organic matter had been consumed. Over this time period fallen trees of several species shed bark, lost strength, and began to collapse onto the ground surface.

Secondary disturbance processes, particularly post-eruption debris slides, were an important feature of the toppled-tree zone. Gully erosion was very limited in the toppled-tree zone because abundant downed forest and micro-topography created by uprooting of trees impeded surface runoff and facilitated infiltration. However, debris slides were widespread on steep $\left(>35^{\circ}\right)$ slopes. Beginning about $200 \mathrm{~m}$ down from the north rim and extending an additional $\mathrm{km}$ downslope, debris slides have removed trees, tephra, and pre-eruption soil from extensive areas of steep hillslopes (Fig. 9). There are three possible mechanisms of post- or syn-eruption debris slide initiation. One mechanism is that on very steep slopes, the blast current toppled trees and immediately carried them downslope on the same trajectory and into a stream channel. An alternative mechanism for debris slide initiation is tree toppling by the blast, followed by sliding under the influence of gravity. A third mechanism of debris slide initiation is that uprooting of trees as they toppled immediately reduced the contribution of tree roots to soil strength, so that subsequent, intensive rainfall on marginally stable slopes triggered increased debris slide activity, which has been observed at Mount St. Helens (e.g., Swanson et al., 1983). Whatever the cause for slide initiation, it is important to recognize that debris slides are a secondary process to the primary volcanic process (the blast) and its immediate impact 


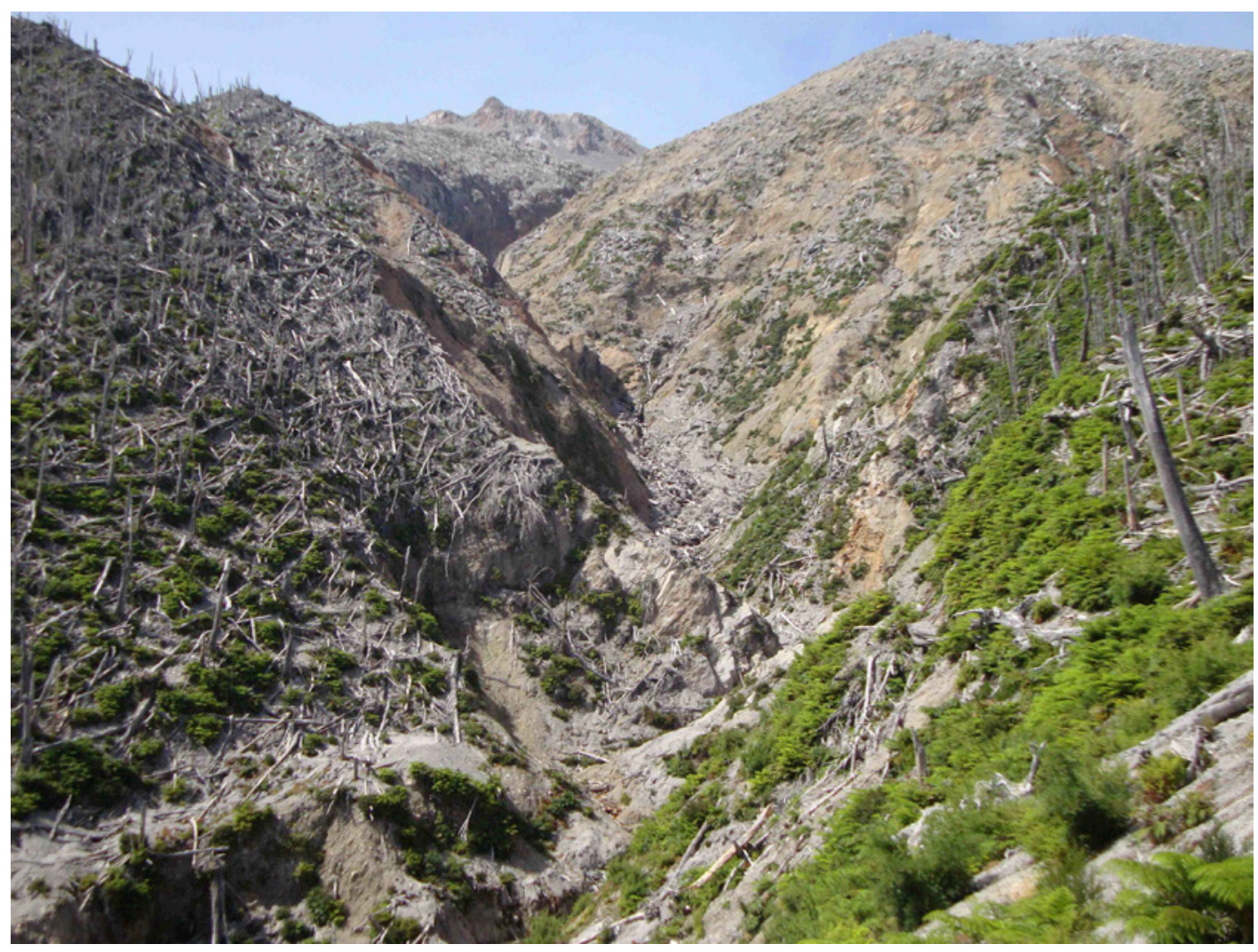

FIG. 9. Upper north flank looking upslope. Note hillslopes (right center) where most toppled trees and soil slid into the stream channel below, forming a thick deposit. Areas that did not slide have toppled trees. (Photo: F. Swanson, January 2012).

(toppling trees). The presence of toppled forest in areas among the debris slide scars indicates that the force of the blast current alone was not sufficient to remove all the forest. If not recognized in geophysical research, the debris slide scars could be erroneously included within a primary, tree-removal impact zone, leading to mistaken inferences about the force of the blast current. An ecological implication of extensive debris slides is that soil removal and the slow pace of subsequent soil development on exposed sub-soil will constrain long-term ecosystem response.

\subsubsection{Scorch zone}

Spatial patterns of tree damage in the $0.7 \mathrm{~km}^{2}$ scorch zone varied according to proximity to the adjacent blast zone and the direction and intensity of the blast current. The scorch zone consisted of standing trees where foliage was scorched by the blast PDC, but where impact force and abrasion were insufficient to topple or immediately defoliate the trees (Fig. 5). This zone was as narrow as a few tens of meters in some sites where the PDC was flowing parallel to the lateral boundary of the scorch zone, and more than $100 \mathrm{~m}$ wide where the blast current flowed directly into the forest. The eastern lateral boundary of the blast zone does not now have a scorch zone because the gravel rain removed foliage and twigs. In some places, trees were toppled into the scorch zone, blurring the boundary. The distal boundary of the scorch zone in the vicinity of Route 7 appears to have lifted up into the forest canopy, leaving the treetops scorched, but middle and lower vegetation strata undamaged.

Tephra and blast deposits in the scorch zone varied from 7 to $8.5 \mathrm{~cm}$ thick (BS01, Fig. 2). The deposits include 2 to $3.5 \mathrm{~cm}$ of gravelly blast deposit supporting lithic clasts to $1 \mathrm{~cm}$ and pumice to $2 \mathrm{~cm}$, and an overlying sandy unit of undifferentiated, latestage blast-current deposition and tephra fall origin (Alfano et al., 2011; Major et al., 2013, this volume). 
Stratigraphy of the upper unit is not well resolved in part because the material passed through the tree canopy, which may result in mixing of tephra units temporarily caught in the canopy.

Observations of trees in the scorch zone revealed no evidence of charring of exposed plant matter, but both the scorching of foliage and pattern of sprouting from trunks and major branches suggested moderate heating. From 2009 to 2011, several species of trees were sprouting from trunks and larger branches, but not from small branches and twigs (Fig. 10, Table 2). This suggests that heating may have damaged epicormic buds on twigs and small branches with thin bark (branch diameter $<10-20$ $\mathrm{cm}$ ), preventing sprouting in these parts of the tree structure. The canopies did not immediately lose many epiphytes, twigs, or branches during the event, which indicates that abrasion, impact force, and canopy loading by the blast current and tephra fall were insufficient to leave clear evidence of damage by these mechanisms in the scorch zone. Dead foliage and epiphytes fell out of the canopy over several months following the explosive phase of the eruption and accumulated on the ground surface, initiating soil development on the new surface.

Stand-level observations indicated that the scorch zone occurred in old forest situated in a poorly drained area near the base of the north flank. Large trees in the plot were predominantly Weinmannia, with a few Nothofagus and small understory trees of Amomyrtus luma, Caldcluvia, Drimys, Embothrium coccineum, Tepualia stipularis, and Podocarpus nubigena. Compared to the toppled-tree zone, the pre-eruption forest in the scorch zone had higher stem density $(750$ trees ha-1), smaller stems (mean diameter $25 \mathrm{~cm}$ ),

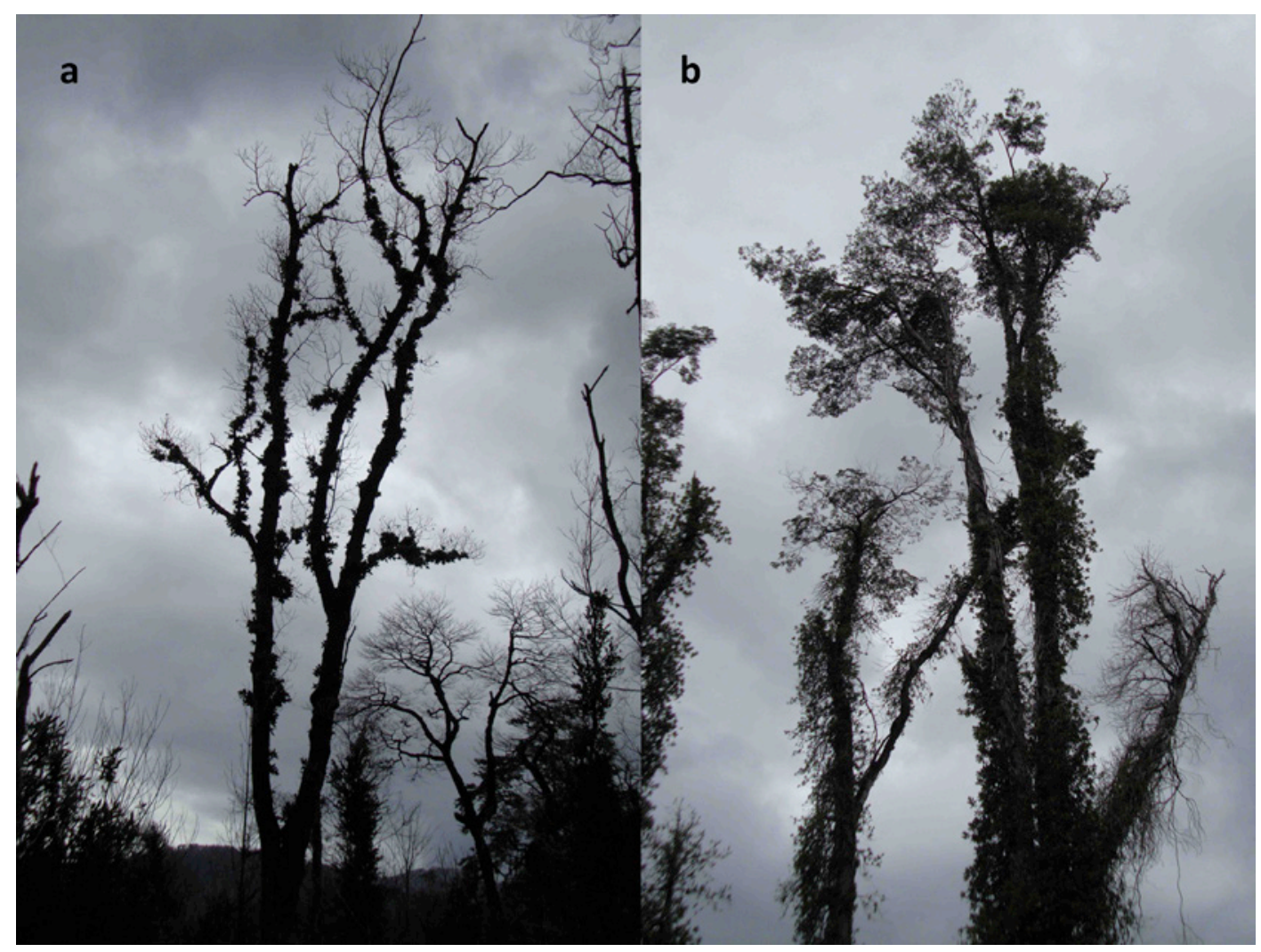

FIG. 10. Profiles of trees sprouting after the Chaitén eruption. a. In the scorch zone sprouting occurred from trunks and major branches, but not small branches and twigs (site BS01, Fig. 2); b. In the Michinmahuida River valley, where about $10 \mathrm{~cm}$ of fine tephra caused substantial branch breakage (site TF05, Fig. 1). Note sprouting from branch tips, which is possible because buds were not killed by heating, as was the case in the scorch zone. Foliage along the tree trunks is dominantly lianas. (Photos: F. Swanson, January 2010). 
and less basal area $\left(58 \mathrm{~m}^{2} \mathrm{ha}^{-1}\right)$ (Table 2). Survival was much higher than in the toppled-tree zone: in January 2010 (18 months after the eruption) 71\% of trees in the scorch zone plot were still alive, $24 \%$ of trees appeared to have been killed by scorching, and $6 \%$ of trees appeared to have been dead before the eruption. Systematic observations in the plot indicated that there was very little sprouting from fine twigs, but $53 \%$ of living trees were sprouting from branches or the trunk, and sprouting occurred on all sizes of trees. Scorching appeared to have killed mostly small trees (diameter $<20 \mathrm{~cm}$ ). As in the toppled-tree zone, sprouting vigor declined over time; two of the largest trees had sprouted, but then the sprouts died. None of the trees was uprooted or broken (Table 2).

\subsubsection{Vegetation response to other PDC processes}

We also observed vegetation response to other PDC processes elsewhere around Chaitén Volcano (Major et al., 2013, this volume) where we did not establish plots. A PDC on the east side of the volcano spilled out of the caldera and down East Breach Creek, creating thick deposits in the vicinity of the confluence with East River (Fig. 2) (Major et al., 2013, this volume). A brief reconnaissance visit to this site (observation point 2, Fig. 2) reveals that at least $3 \mathrm{~m}$ of pumice-rich sand and fine gravel inundated an extensive tract of old forest (Major et al., 2013, this volume). Overstory tree mortality appeared to be complete. All twigs and foliage had been stripped, and tree canopies had experienced approximately $80 \%$ branch loss. The absence of foliage on the deposit surface suggests that these structures were stripped early in the sequence of events affecting the site, while the complex jumble of branches on the deposit surface indicates collapse of branch structures late in the sequence of events or subsequently. We observed no charring of trunks or downed branches. Similarly, the absence of evidence of toppling or shearing of large trees indicates a disturbance of relatively low impact force. In our two hour survey of about two hectares, we observed only three vestiges of residual vegetation: a single sprig of Chusquea that had penetrated the PDC deposit along a slump fracture, a single cluster of Mitraria (epiphyte) growing on a tree trunk, and a single small sprout from the trunk of a Weinmannia tree.

We also visited the northwest side of the moat between the inner caldera wall and the lava dome (observation point 3, Fig. 2) in January 2012. Tephra fall and PDC deposits there are many meters thick. We did not observe any living plants; the only organic plant material observed was a single charred and partially buried tree trunk.

\subsection{Airfall tephra zone: physical processes and forest conditions}

Chaitén erupted explosively for about 10 days followed by $\sim 18-20$ months of an effusive phase of dome growth within the caldera (Pallister et al., 2013, this volume). Tephra production occurred throughout this period, but mainly in the early weeks of the eruption (Alfano et al., 2011). We describe interactions between tephra fall and forests within about $30 \mathrm{~km}$ of Chaitén where texture and thickness of deposits vary substantially. We consider three cases of tephra depth and texture, which resulted in distinctive effects on forests: thick $(>5 \mathrm{~cm})$, coarse tephra (referred to as 'gravel rain'); thick $(>10 \mathrm{~cm})$, fine-grained tephra; and thin $(<10 \mathrm{~cm})$, fine-grained tephra.

\subsubsection{Gravel rain}

Spatial patterns of tree damage in the gravel-rain zone include areas of trees that have been abraded by vertical tephra fall, and small areas of trees toppled and abraded by a laterally moving current. The Plinian eruption of 6 May 2008 produced a distinctive, gravel-sized tephra that fell in a narrow plume extending to the north-northeast, the $\beta$ layer of Alfano et al. (2011). This layer exceeded $5 \mathrm{~cm}$ thickness over an area of approximately $50 \mathrm{~km}^{2}$ (Fig. 1). In the gravel-rain zone, forests show evidence of predominantly abrasion by gravel falling vertically. Stratigraphic studies, described below, indicate that $5 \mathrm{~cm}$ of tephra fall accomplished the majority of the abrasion. Within the gravel-rain zone small areas of forest also exhibit effects of lateral abrasion and impact force indicative of downslope movement of some type of density current containing rock debris. For example, in several locations near the Rayas River bridge (near TB01, Fig. 2), trees and Chusquea were toppled in a downslope direction; lithic clasts were embedded in the upslope sides of soft, rotten, long-dead tree trunks; and epiphytes were scoured from the upslope sides of trees (Fig. 11). These sites are at the bases of long, steep slopes only 3 to $4 \mathrm{~km}$ from the vent. However, this area was not affected by any of the PDCs documented by Major et al. 
(2013, this volume). Patches of toppled and laterally abraded trees in the vicinity of TB01 are distinctly disconnected from evidence of any PDC originating at the caldera rim. This disconnection suggests that this forest disturbance may have resulted from one or more density-current downbursts from the underside of the eruption plume as prevailing wind moved it away from the vent. Once the downburst reached the ground it was guided downslope as a flowing density current by local topography. Along the central axis of the gravel-rain plume at sites well removed from steep slopes and several $\mathrm{km}$ farther from the vent (TB02, TB03, Fig. 1), we found evidence of only vertical fall of gravel tephra, and no lateral, abrasive, forceful current.

Tephra deposits in the gravel-rain zone included the $\beta$ gravel unit overlain by sandy airfall tephra (TB01, TB02, TB03, Fig 1, 6; Table 4). The $\beta$ layer at these sites ranges in thickness from 13 to $16 \mathrm{~cm}$, and is commonly overlain by 4 to $6 \mathrm{~cm}$ of sandy airfall tephra. The inorganic fraction of the $\beta$ layer consisted of massive, uniformly graded gravel composed of 50-90\% lithic clasts; the remainder was pumice. At a distance of $4 \mathrm{~km}$ from the vent, the long axis of the largest lithic particles was about $10 \mathrm{~cm}$; at a distance of $6 \mathrm{~km}$, it was $6 \mathrm{~cm}$. Particles of this size can easily scour tree canopies, entraining foliage, twigs, and canopy epiphytes in the gravel-rain deposits. Excavation of gravel-rain deposits in 5-cm-thick stratigraphic increments at several sites in the vicinity of TB01 and TB02 (Fig. 2) revealed that the basal $5 \mathrm{~cm}$ contained the greatest abundance of organic matter (Fig. 12). Such a concentration of organic matter indicates that the bulk of initial canopy damage occurred during the earliest phase of deposition of the gravel rain. We observed no evidence of charring of the abundant organic matter incorporated in the deposit.

Many features of vegetation were affected by gravel rain. Gravel-sized, lithic tephra particles were sufficiently dense and large that they were not deposited in the canopy, but rather passed through and abraded the canopy (Fig. 13). Some branches appeared to have fallen during the eruption in the vicinity of TB01 (Fig. 2) in response either to the lateral surge or the pelting of marginally stable branches by the intense, vertical rain of gravel tephra. Where Chusquea and other tall understory plants remained upright through part or all of the tephra fall, their
TABLE 4. SUMMARY OF TOTAL TEPHRA THICKNESS AND THICKNESS OF $\beta$ (GRAVEL) LAYER AT SAMPLED PLOTS.

\begin{tabular}{|c|c|c|c|c|}
\hline code & $\begin{array}{c}\text { Total } \\
\text { thickness } \\
\text { mean } \\
(\mathrm{cm})\end{array}$ & SD & $\begin{array}{c}\text { gravel } \\
\text { thickness } \\
\text { mean } \\
\text { (cm) }\end{array}$ & SD \\
\hline \multicolumn{5}{|c|}{ Blast zone-tree removal } \\
\hline BR01 & $75+$ & $35+$ & $75+$ & $35+$ \\
\hline \multicolumn{5}{|c|}{ Blast zone-toppled tree } \\
\hline ВT03 & 16.0 & & -- & -- \\
\hline ВT02 & 21.7 & 5.9 & 17.3 & 4 \\
\hline ВT02 & -- & -- & -- & -- \\
\hline ВT01 & 33.3 & 16.9 & 25.0 & 12.1 \\
\hline BT01 & -- & -- & -- & -- \\
\hline \multicolumn{5}{|c|}{ Blast zone-scorch } \\
\hline BS01 & 7.8 & 0.8 & 2.8 & 0.8 \\
\hline \multicolumn{5}{|c|}{ Airfall tephra-gravel rain } \\
\hline TB01 & 22.1 & 7.5 & 15.8 & 7.4 \\
\hline TB01 & -- & -- & -- & -- \\
\hline TB02 & 22.6 & 2.3 & 15.6 & 1.1 \\
\hline ТВ03 & 20 & 1.4 & 13 & 0 \\
\hline \multicolumn{5}{|c|}{ Airfall tephra-fine tephra } \\
\hline TF01 & 7.7 & 1.2 & $\mathrm{n} / \mathrm{a}$ & $\mathrm{n} / \mathrm{a}$ \\
\hline TF02 & 6.7 & 0.7 & $\mathrm{n} / \mathrm{a}$ & $\mathrm{n} / \mathrm{a}$ \\
\hline TF04 & 14.1 & 1.7 & $\mathrm{n} / \mathrm{a}$ & $\mathrm{n} / \mathrm{a}$ \\
\hline TF05 & 10.4 & 1.4 & $\mathrm{n} / \mathrm{a}$ & $\mathrm{n} / \mathrm{a}$ \\
\hline TF06 & 12.0 & 2.8 & $\mathrm{n} / \mathrm{a}$ & $\mathrm{n} / \mathrm{a}$ \\
\hline \multicolumn{5}{|c|}{ Floodplain-fluvial deposition } \\
\hline FF01 & $75+$ & -- & $\mathrm{n} / \mathrm{a}$ & $\mathrm{n} / \mathrm{a}$ \\
\hline FF02 & $75+$ & -- & $\mathrm{n} / \mathrm{a}$ & $\mathrm{n} / \mathrm{a}$ \\
\hline
\end{tabular}

'--' = not measured; 'n/a'= no gravel layer observed; 'SD' = standard deviation.

rigid stems are found in the upper parts of the tephra profile (Fig. 12). In some cases Chusquea and other understory plants extend through the deposit. The gravel rain at site TB01 killed the abundant, large (stem diameter to $6 \mathrm{~cm}$ ) lianas that formed a sheath that nearly enclosed the trunks of many of the large trees in the old forest (Fig. 11). By January 2010 some of these sheaths of lianas had collapsed to the ground. Sprouting was very common in the gravel rain zone, including from branches and trunks of 


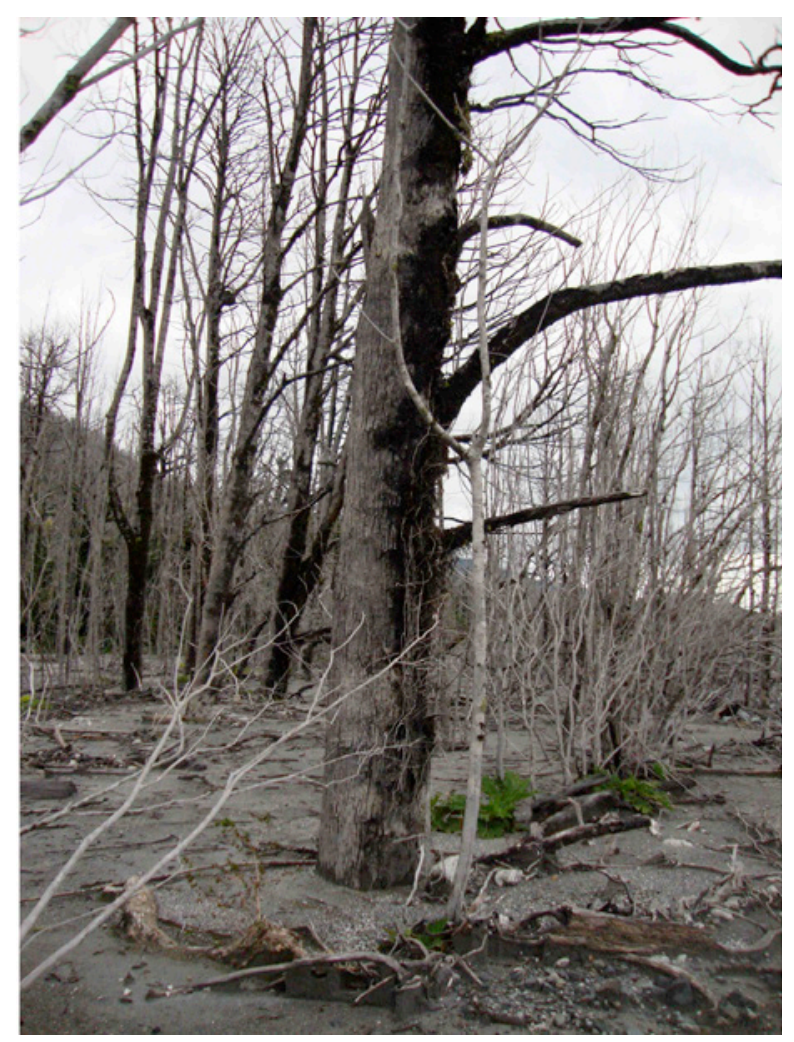

FIG. 11. Epiphytes abraded from the left side of the tree trunk by lateral movement of gravel tephra during the $\beta$ tephra fall event (Alfano et al., 2011) at a site adjacent to the Rayas River bridge (near TB01, Fig. 2). (Photo: J. Jones, January 2011).

trees that had lost foliage, twigs, and branches as a result of abrasion.

Stand-level observations indicated that prior to the eruption, the gravel-rain zone consisted of forests of varied structure and composition; these factors as well as proximity to the vent and the nature of the disturbance process (lateral surge or only vertical tephra fall, Table 2) determined the effect of gravel rain on the forest. We sampled in sites of both old and young pre-eruption forest, which had rather similar basal area, but a 10-fold difference in stem density (Table 2). The old forest plot affected by 16 $\mathrm{cm}$ of gravel rain (TB01, Fig. 2) also was affected by a lateral surge. As a result, $11 \%$ of stems in the plot had been uprooted, but none was snapped off. This patch of old forest was less species-rich than the toppled-tree zone, and had a relatively sparse canopy dominated by large trees of Weinmannia and Laureliopsis, with smaller understory trees of $A$. luma or A. meli and Caldcluvia, and a great deal of Chusquea. Forest structure was comparable to that in the toppled-tree zone, but with fewer (259 stems $\mathrm{ha}^{-1}$ ), larger (mean diameter of $51 \mathrm{~cm}$ ) trees, and an intermediate basal area $\left(86 \mathrm{~m}^{2} \mathrm{ha}^{-1}\right)$ (Table 2). In January 2010, mortality was comparable to the scorch zone (about $20 \%$ of trees appeared to have been killed by the initial gravel rain, and $6 \%$ appeared to have been dead before the eruption; Table 2). Consistent with observations of sprouting in the toppled-tree zone, all live stems (Weinmannia and Laureliopsis) were sprouting in January 2010, but by 2012, only 50\% of trees were still alive (Table 2). In 2012, only two of eleven Weinmannia trees (diameter ranging from 66 to $150 \mathrm{~cm}$ ) were sprouting vigorously; all or most of the sprouts on the other large trees had died. In contrast, surviving small understory trees of $A$. luma (diameter ranging from 6 to $25 \mathrm{~cm}$ ) were sprouting vigorously along their trunks as of 2012, although all had experienced dieback of the upper 10 to $70 \%$ of stem length. Very few broken branches occurred on the surface of the tephra fall deposits, consistent with stratigraphic interpretations that most canopy 


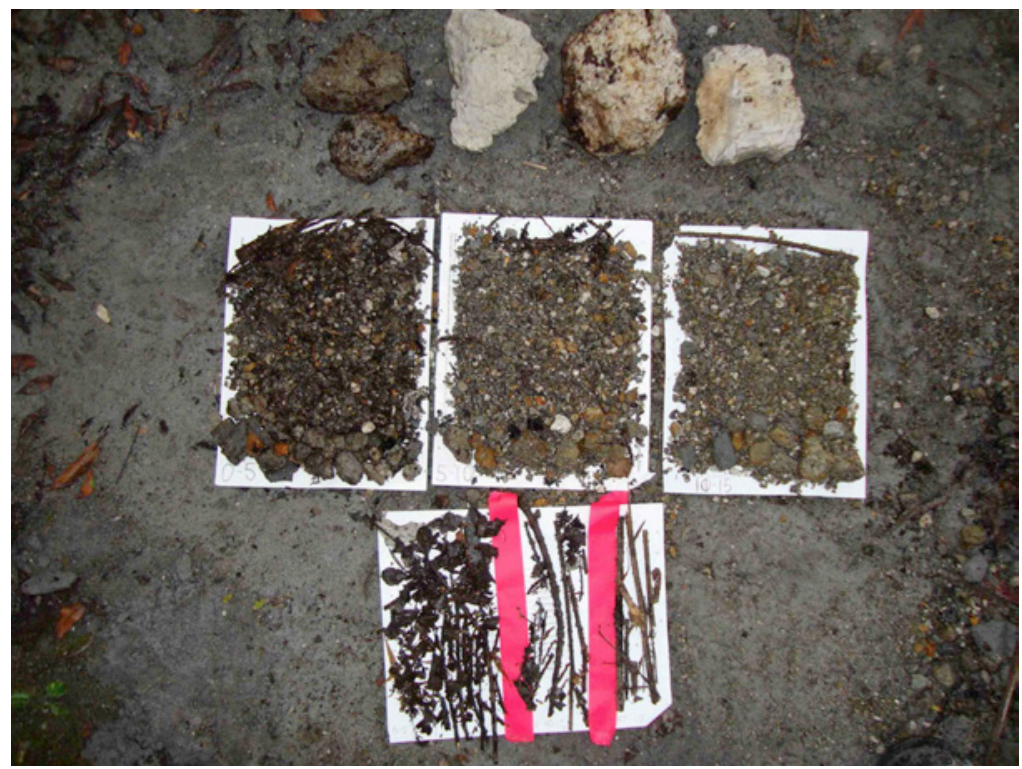

FIG. 12. Tephra and organic matter in the gravel-rain disturbance zone ( $\beta$ layer of Alfano et al., 2011) near Rayas River (TB01, Fig. 2). The 15-cm-thick deposit was sampled in 5-cm vertical increments and organic matter was hand sorted for each layer. Deeper to shallower layers are arranged left to right. The upper three white sheets contain the total mineral plus organic material from each of the three 5-cm layers. The lower white sheet displays the organic material from each layer, deeper to shallower layers arranged left to right, separated by red flagging tape. Large pumice and lithic clasts across the top of the photo were found on the ground surface within a radius of $10 \mathrm{~m}$ of the pit. The 1-cm-diameter sticks in all three layers are Chusquea stems that penetrated the whole deposit. White sheets are $28 \mathrm{~cm}$ long. (Photo: F. Swanson, January 2011).

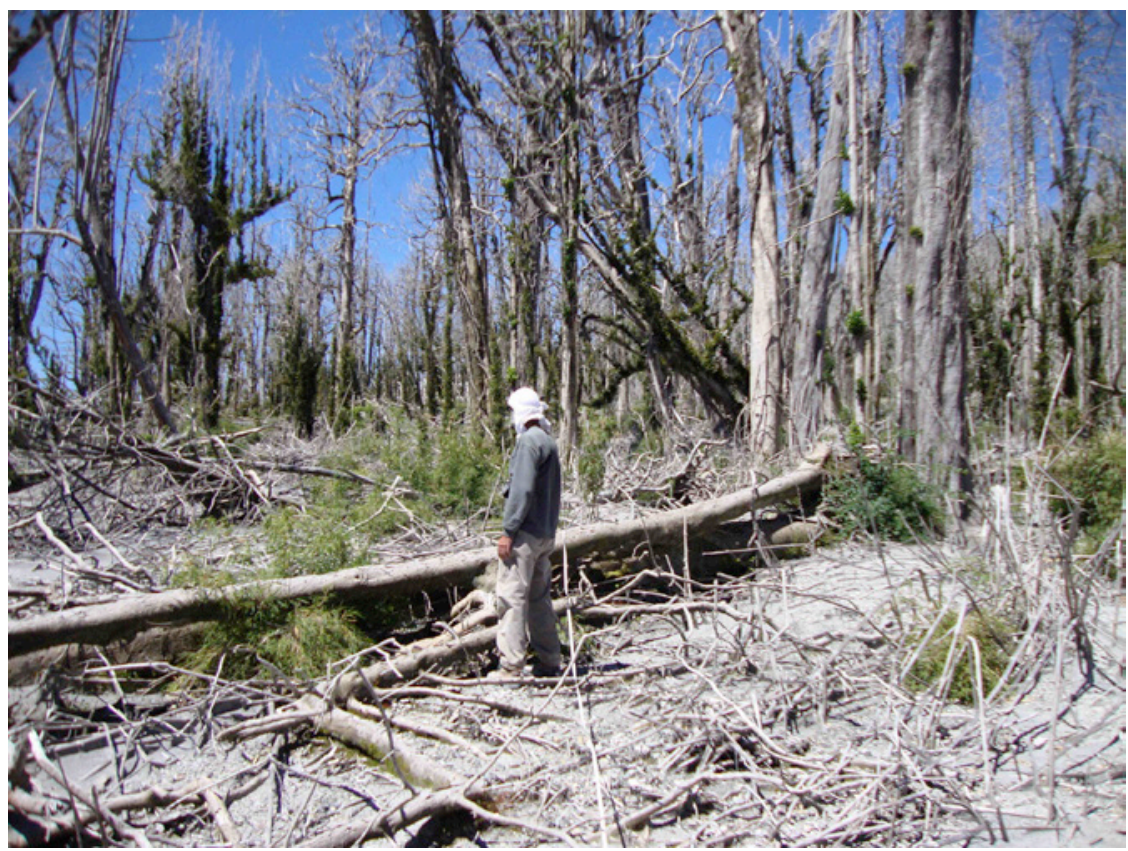

FIG. 13. Forest damage (foliage and fine twig abrasion) and meager sprouting in the gravel-rain disturbance zone. This site (TB01, Fig. 2) received $16 \mathrm{~cm}$ of gravel, dominantly lithic tephra fall, and an additional $5 \mathrm{~cm}$ of fine tephra. (Photo: J. Jones, January 2010). 
damage and branchfall occurred during, not after, the event (Table 3 ).

The sites of our younger forest plots affected by gravel rain (TB02, TB03, Table 2) did not experience a lateral surge. This young forest had an overstory dominated by Eucryphia, N. dombeyi, and Weinmannia and small understory trees of A. meli, Drimys, and Tepualia with little to no Chusquea. Despite a much higher density $\left(2,200-2,400\right.$ stems $\left.^{-1}\right)$ of smaller stems (mean diameter $15-16 \mathrm{~cm}$ ) the forest at TB02 and TB03 had a basal area (63 to $\left.73 \mathrm{~m}^{2} \mathrm{ha}^{-1}\right)$ similar to the old forest affected by gravel rain (TB01). Also, these young forest sites had mortality similar to the old forest in response to gravel rain: in January 2012, $52 \%$ to $74 \%$ of trees in the plots were still alive, 13 to $35 \%$ had been killed by the eruption, and $12 \%$ appeared to have been dead before the eruption. Unlike scorch, gravel-rain damage did not impede sprouting from the residual twigs and small branches. In one plot where roughly half of the trees were still alive, $27 \%$ of trees were sprouting from twigs, $10 \%$ from branches, and $48 \%$ from trunks. In the site where roughly three-quarters of the trees were still alive, $55 \%$ of trees were sprouting from the twigs, $22 \%$ from branches, and 39\% from trunks.

In 2010 we visited a site of 50-cm-thick gravel deposit of the $\beta$ tephra unit at the confluence of the Rayas River and East River (observation point 1, Fig. 2). The majority of the deposit was composed of coarse sand to fine gravel and contained abundant fragments of foliage, small twigs, and lichens near the base of the deposit. Signs of surviving plant life were present, but extremely rare. The mixed-aged, broadleaf, evergreen forest experienced complete mortality of overstory foliage, but several species, notably A. luma, were sprouting vigorously from the trunks. Podocarpus trees had limited sprouting, as did Lomatia ferruginea. Most other tree species showed no evidence of sprouting, and tree foliage cover was estimated to be $<1 \%$ of pre-eruption values. Epiphytes experienced high mortality $(\sim 80 \%)$, but several species had initiated new, vigorous growth. The forest understory was mostly killed, with only scatted individuals of living Chusquea and Blechnum ferns. Total understory plant cover values were $<1 \%$.

\subsubsection{Thick deposits of fine tephra}

Spatial patterns of vegetation damage in the zone of thick $(>10 \mathrm{~cm})$ deposits of fine tephra ranged from complete canopy collapse to only partial loss of foliage. This heterogeneity is attributable to the very large area affected, the highly variable topography and vegetation, and variable thicknesses of airfall tephra, which locally exceeded $1 \mathrm{~m}$ (Alfano et al., 2011) (Fig. 1). The effects of airfall tephra were complicated in areas where it was deposited in other volcanic disturbance zones (Fig. 1). Several layers of fine tephra were deposited over the $\beta$ layer (Alfano et al., 2011). Moreover, despite its extent $\left(480 \mathrm{~km}^{2}\right)$, most of the area with $>10 \mathrm{~cm}$ of airfall tephra deposits was very difficult to access, so our observations are based on sandy tephra units from sequences as thick as $15 \mathrm{~cm}$ along roads and trails in the Amarillo and Michinmahuida River valleys, $20 \mathrm{~km}$ southeast of the vent (Fig. 1).

Tephra deposits in the zone of thick, fine tephra revealed aspects of the interaction of fine tephra with the forest canopy. Based on sampling soon after the eruption, Alfano et al. (2011) made detailed descriptions of tephra stratigraphy in sites lacking forest cover. Some of these sites are near our plots with thick deposits of fine tephra, which are under forest canopies (plots TF04-TF06, Fig. 1), where we found deposit thickness ranging from 10 to $14 \mathrm{~cm}$ (Table 4). In contrast to stratigraphy in open sites, leaf litter was dispersed throughout the upper several centimeters of the thick, fine-grained tephra profile under the forest canopy. This suggests that some tephra was retained temporarily in the canopy and then fell to the ground as leaves detached from stems. Basal units of the fine tephra deposits did not contain abundant organic matter, in contrast to coarse-grained deposits under canopies abraded by gravel rain.

Observations of trees in the zone of thick, fine tephra revealed distinctive forest damage that varied by tree age, species, and protection of adjacent trees. The accumulation of fine tephra in tree crowns, which we call 'canopy loading', led to broken branches, bowing of stems, localized toppling, and partial burial. We did not observe any evidence of charring, abrasion, or impact force in this zone; manifestations of canopy loading were common, but not ubiquitous. Tree architecture, which varied by species and age, influenced the effects of canopy loading. For example, Podocarpus, which has rigid, upright, evergreen, needle-like leaves, was particularly effective in catching tephra. In 2009 we found cases of tips of Podocarpus branches still attached to trees buried in tephra on the ground; these branch tips remained buried through our 2012 sampling and 
quite a bit of tephra was still lodged in the foliage. Branch breakage was especially common in large, old trees, which had large, horizontal branches. Bowing of stems was common in young, flexible trees. Small trees outside the protection of large overstory trees were prone to being bowed over. In old forest sites experiencing a great deal of branch fall (Table 3, Fig. 14), the canopy was opened, triggering a positive growth response of epiphytes and foliage that remained on the trees (Fig. 10).

Stand-level observations indicated that prior to the eruption, the zone of thick deposits of fine tephra consisted of both old and young forest, which responded differently to deposits of 10 to $15 \mathrm{~cm}$ of airfall tephra. At old forest plots (TF05, TF06; Fig. 1), pre-eruption forests had a relatively sparse canopy dominated by large trees of Laureliopsis and $N$. dombeyi (although some of the $N$. dombeyi had been selectively logged), the small understory tree A. luma, the tall shrub Azara lanceolata, and locally thick patches of Chusquea. The pre-eruption forest was structurally similar to the old forest affected by gravel rain, with relatively few large trees (425 to 550 stems ha ${ }^{-1}$ with a mean diameter of 23 to $41 \mathrm{~cm}$ ) and low basal area (48 to $89 \mathrm{~m}^{2}$ ha-1) (Table 2). Airfall tephra had a minor effect on tree mortality: in old forest plots, which were measured on different dates (January 2010 and January 2012), about $80 \%$ of trees were still living, 10\% appeared to have been killed by the eruption, and about $10 \%$ appeared to have died before the eruption. Airfall tephra deposits in old forests led to considerable breakage of large branches: we observed 44 branches per $100 \mathrm{~m}$ transect with an average diameter of $11.5 \mathrm{~cm}$ on the forest floor at TF05 in January 2010, and 105 branches per $100 \mathrm{~m}$ with an average maximum diameter of $8 \mathrm{~cm}$ on the forest floor at TF06 in January 2012 (Table 3). Loss of branches from the canopy led to sprouting from remaining branches and trunks. In January $2010,27 \%$ of trees were sprouting from branches (plot TF05, Table 2); in January 2012, $35 \%$ of trees were sprouting from twigs, $27 \%$ from

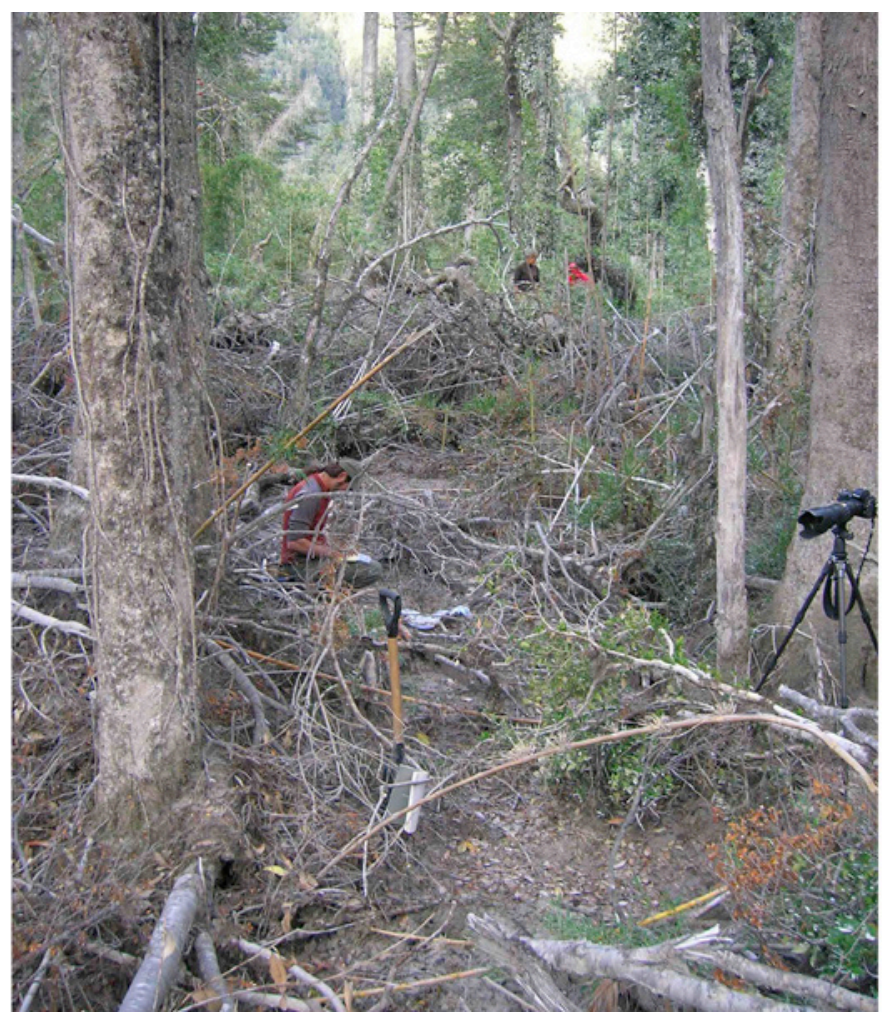

FIG. 14. Branch-sized litter near site TF06 in the Michinmahuida River valley (Fig. 1) where $12 \mathrm{~cm}$ of fine tephra was deposited in old forest. (Photo: F. Swanson, February 2009). 
branches, and $61 \%$ from trunks (note that sprouting could occur from more than one location on a tree) (plot TF05, Table 2).

In contrast, thick deposits of fine tephra had different effects on young forest, which had many more small trees $\left(3,356\right.$ stems ha $^{-1}$, mean diameter of $11 \mathrm{~cm})$, an intermediate basal area $\left(71 \mathrm{~m}^{2} \mathrm{ha}^{-1}\right)$, and was dominated by $N$. dombeyi, with small understory trees of $A$. meli and a few remnant large Weinmannia (TF04, Fig. 1, Table 2). In young forest, thick deposits of airfall tephra had almost undetectable effects on tree mortality. Ninety-three percent of trees were alive in January 2011, 5\% appeared to have died before the eruption, and only $2 \%$ appeared to have been killed by the effects of the eruption (TF04, Table 2). Loss of foliage in the canopy appeared to have stimulated sprouting, even by $N$. dombeyi, which was not observed to sprout in any other plots. In January 2011, 50\% of trees were sprouting from twigs, branches, and/or trunks (TF04, Table 2).

In January 2010 we briefly visited one additional site where tephra deposits greatly exceeded $15 \mathrm{~cm}$. The site (observation point 4, Figs. 2, 15) was located along the upper Chaitén River $3 \mathrm{~km}$ south of the caldera rim, where sand to fine gravel tephra deposits (lithic clasts to $1 \mathrm{~cm}$ ) were $>50 \mathrm{~cm}$ deep. Initially it appeared that the native forest had been completely killed, but on closer inspection we found a few shrubs sprouting foliage and living lianas on the undersides of fallen trees. Most of forest had collapsed under the tephra load, perhaps accentuated by addition of rainfall to the tephra retained in the canopy. Trunks of most trees $>30 \mathrm{~cm}$ in diameter remained standing, but had experienced extensive branch breakage. Smaller trees and large shrubs were bent over and in some cases had snapped stems and branch tips buried in tephra on the ground.

\subsubsection{Thin deposits of fine tephra}

Spatial patterns of vegetation damage in the zone of thin deposits of fine tephra were ephemeral, difficult to observe, and difficult to distinguish from non-volcanic processes affecting forests. From tephra distribution maps in Alfano et al. (2011) we estimate that fine tephra fall of at least $1 \mathrm{~mm}$ affected an area of approximately $40,000 \mathrm{~km}^{2}$ extending well into Argentina. With increasing distance from the vent,

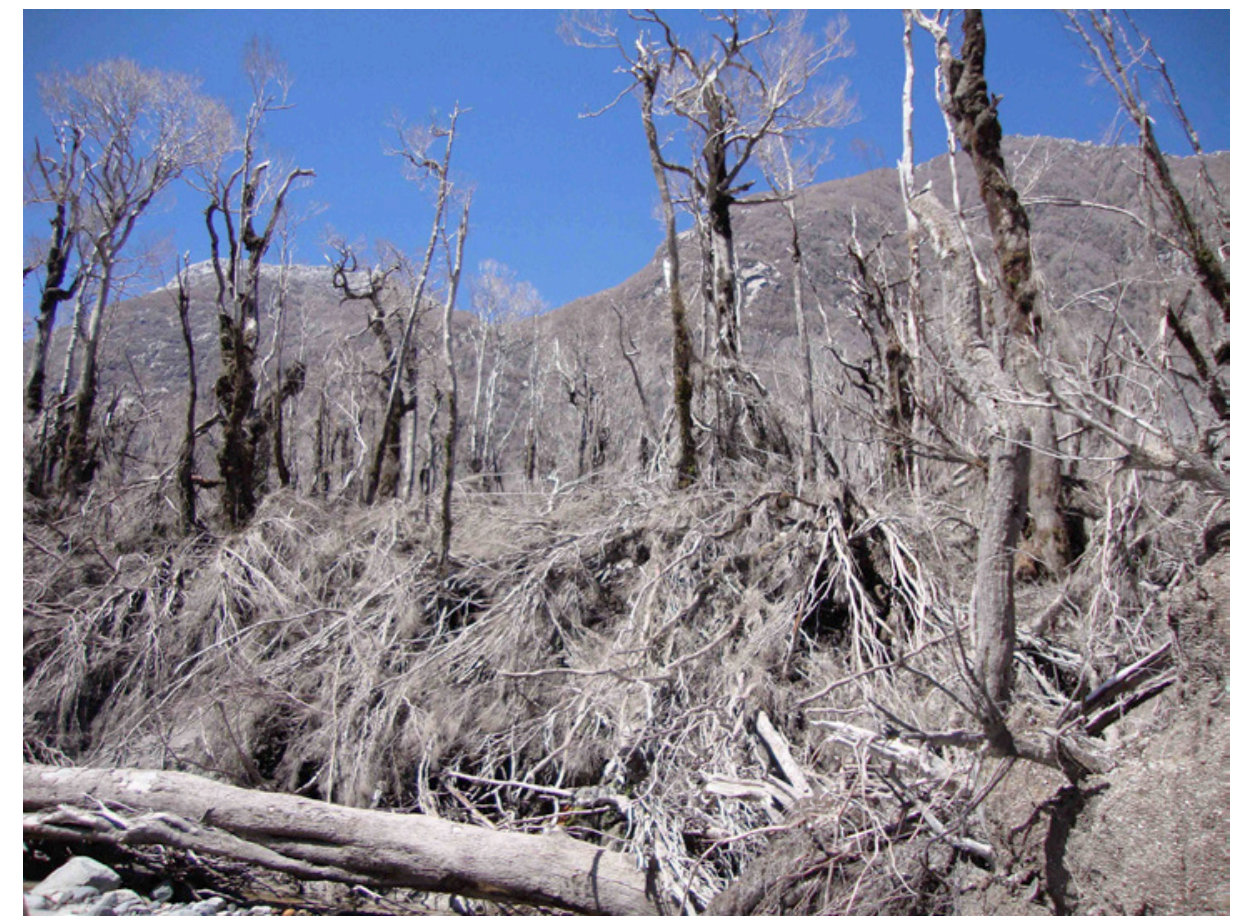

FIG. 15. Fallen shrubs and standing trees with loss of limbs at site having approximately $50 \mathrm{~cm}$ of fine-grained tephra deposit along the upper Chaitén River at observation point 4 (Fig. 2). Note that stream bank is in lower foreground. (Photo: J. Jones, January 2010). 
tephra generally thins and grades from fine gravel and coarse sand to silt.

Thin, fine-grained tephra deposits were greatly affected by interaction with the forest canopy. We established plots in several locations northwest of the vent (TF01, TF02, Fig. 2) and have an additional observation point (point 5, Fig. 1) south of the volcano which have deposits of fine tephra (medium to coarse sand) $<10 \mathrm{~cm}$ thick. Alfano et al. (2011) provide detailed descriptions of stratigraphy at sites near these plots, but the fine distinctions they make are probably not significant from an ecological perspective. In tephra profiles under forest canopy we observed leaves incorporated in the upper 1 to $2 \mathrm{~cm}$ of the fine-tephra sequence, indicating that tephra was temporarily deposited in the canopy, then fell to the forest floor later along with the foliage that had helped trap it.

Observations of trees indicated that thin deposits of fine tephra had much less conspicuous impact on vegetation than processes affecting other disturbance zones described in this paper. Stand-level observations indicate that forests affected by thin fine tephra deposition experienced no detectable tree mortality (TF01, TF02, Fig. 2, Table 2). Canopy loading appeared to be insignificant: only rare, small broken branches were observed on the forest floor (less than 10 branches occurred per $100 \mathrm{~m}$ of transect) (Table 3 ). Inspection of a site along the Negro River (observation point 5, Fig. 1), which received $4 \mathrm{~cm}$ of coarse-sand tephra in native forest of large (diameter of $80+\mathrm{cm}$ ) trees, revealed dieback of foliage on branches of 2 to $5 \mathrm{~cm}$ diameter on Caldcluvia, Weinmannia, and Laureliopsis, but these dead branches affected only about one percent of total leaf area of individual trees. We are not able to conclusively attribute this branch mortality to impacts of the eruption.

\subsection{Fluvial and pyroclastic flow deposition on floodplains}

Major river valleys draining volcanoes are subject to extraordinary inundation by flow processes involving water and volcanic sediment during and immediately following eruptions. In the first two weeks of the Chaitén eruption, tephra blanketed the headwaters of the Rayas and Chaitén River watersheds. This set the stage allowing even moderate rainfall to trigger rapid runoff and erosion from hillslopes, which sent tephra-charged flood waters down these rivers (Pierson et al., 2013). Nearly ten months later, partial collapse of the dome growing within the caldera (Pallister et al., 2013, this volume) triggered a pyroclastic flow down Caldera Creek and into the Chaitén River valley; this flow extended to within $3 \mathrm{~km}$ of Chaitén town (Major et al., 2013, this volume). We consider these two types of flow processes together because they are both confined to valley floors. Although these processes are restricted in extent, they can have high impact on riverine and riparian ecosystems, and potentially on human life and property.

\subsubsection{Fluvial deposition on floodplains}

Spatial patterns of vegetation damage in the zone of fluvial deposition on floodplains were concentrated along channel margins and in secondary channels. The valley floors and floodplains of rivers draining Chaitén Volcano are flat, with five meters or less of elevation change in typical valley floor crosssections. Extreme runoff from the upper Rayas and Chaitén Rivers aggraded these channels; entrained and transported big wood, which contributed to lateral channel change; and deposited up to several meters of reworked tephra, alluvium, and wood on floodplains and in secondary channels along these rivers. Based on interpretation of remote sensing imagery, rainfall runoff from watersheds intensively impacted by thick airfall tephra deposits resulted in up to $2 \mathrm{~m}$ of fluvial deposition on $5 \mathrm{~km}^{2}$ of forested floodplains over the $19 \mathrm{~km}$ of the Rayas River downstream from the Route 7 highway bridge (near TB01; Fig. 2), which roughly marks the western extent of airfall deposits exceeding about $10 \mathrm{~cm}$ (Fig. 1). Fluvial deposition of remobilized tephra affected portions of forested floodplains along 6 $\mathrm{km}$ of the Chaitén River from its confluence with Caldera Creek downstream to the town.

Burial of floodplain forests occurred on 12-14 May 2008 during the first significant rains that followed the explosive phase of the eruption which deposited nearly all of the tephra fall (Pierson et al., 2013). As of January 2013, the inundated floodplain surfaces along the lower Rayas River appeared to have not been inundated subsequently. Photographs from June 2008 (D. Guzmán, Pumalín Park, personal communication) reveal that the channel had aggraded by several meters, but within a few years it incised and reestablished a bed of large boulders. The river now seems less likely to reoccupy the floodplain 
surfaces on a frequent basis, because they are now 1 to $2 \mathrm{~m}$ higher than before the eruption. Valley floor dynamics along the lower Chaitén River have been more complex, in part owing to deposition of the 19 February 2009 pyroclastic flow.

At the upstream end of floodplain surfaces, large wood was floated into place and wood pieces became lodged against standing trees. These loglevee deposits separated vegetation-free, depositional surfaces close to the channel from patches of forest that were inundated by flooding and sediment, but not subjected to battering by transported wood. Our plots were located in forested floodplain patches that were subjected solely to deposition.

Deposits on floodplains were commonly 1 to $2 \mathrm{~m}$ thick, based on soil pits and streambank exposures. The maximum soil pit depth of $75 \mathrm{~cm}$ did not reach the pre-eruption surface, but deposits were exposed in nearby streambanks in the vicinities of our plots at FF01 and FF02 on the Rayas River (Fig. 2) and 3 and $7 \mathrm{~km}$ upstream from the town of Chaitén on the Chaitén River. The floodplain deposits were weakly stratified sand to fine gravel with rare pumice particles (up to $30 \mathrm{~cm}$ length) on the surface of the Rayas River floodplain. Floodplain deposits in the Chaitén River valley downstream of the confluence with Caldera Creek and upstream of the town contained a much wider variety of particle-size distributions and sedimentary fabrics and structures, reflecting the variety of processes responsible for emplacement, as described by Major et al. (2013, this volume) and Pierson et al. (2013). These processes included water floods and hyperconcentrated flows associated with rainfall runoff, and ash-cloud surges associated with the 19 February 2009 pyroclastic flow and another pyroclastic flow between June and November 2008.

Observations of trees in the zone of fluvial deposition on floodplains revealed sharp-edged patches in which most trees were dead and decomposing by three or four years after the eruption. As of 6 June 2008, more than three weeks after they probably were inundated, forest patches on the Rayas River floodplain appeared to still have green foliage (Fig. 5), but by January 2010 canopies had turned brown, indicating die back of foliage (Fig. 6; also see Major and Lara, 2013, this volume). Foliage of trees killed by burial has subsequently fallen as forest litter (foliage, epiphytes, and twigs) on top of the new deposits, initiating soil formation. When we visited these sites in 2011 and 2012 we found numerous small branches on the surface (Table 3), which appear to have accumulated gradually as a result of decomposition of the killed trees; we saw no evidence of canopy loading either in the area of inundated floodplain or in nearby living forest. Where they were sufficiently thick, the floodplain deposits led to tree mortality by some combination of hypothetical mechanisms, such as disruption of soil-atmosphere gas exchange, rise of the water table into the root zone, or other factors.

Stand-level observations indicate that forests in the zone of fluvial deposition on floodplains were mostly young stands adjacent to active channels. The inundated pre-eruption forest had a high density of small trees $\left(2,100\right.$ to 2,600 stems ha $^{-1}$ with a mean diameter of 15 to $16 \mathrm{~cm}$ ) and a basal area of 76 to $82 \mathrm{~m}^{2}$ ha $^{-1}$ (Table 2). We surmise that these stands originated as primary forest on floodplain surfaces, because adjacent surfaces only a meter or two higher that were not inundated support large, old forest. In the young, inundated forest, the only surviving species from pre-eruption forests were A. meli, Caldcluvia, Drimys, Luma, and Tepualia. Mortality varied as a function of depth of burial. As of January 2012, at a site where deposits were approximately $1 \mathrm{~m}$ thick (FF01, Fig. 2), 43\% of trees were still living, 50\% appeared to have been killed by burial, and 7\% appeared to have died before the eruption. At a site where burial possibly exceeded $2 \mathrm{~m}$ (FF02, Fig. 2 ), as of January 2012 , only $6 \%$ of trees were still living, $82 \%$ appeared to have been killed by burial, and $11 \%$ appeared to have died before the eruption. At both sites, living trees had lost foliage, but twigs and branches were intact and were sprouting primarily from twigs or fine branches (Table 2). The ground surface at both of these sites in January 2012 was littered with relatively high densities of broken twigs ( 37 pieces per $100 \mathrm{~m}$ of transect with mean diameter $3.4 \mathrm{~cm}$, and 111 per $100 \mathrm{~m}$ with a mean diameter of $2.7 \mathrm{~cm}$ ). We interpret these branches to be litterfall from canopies that had been killed by burial 3.5 years before.

Other observations of fluvial deposition on floodplains indicate that floodplain deposits interacted with micro-topography to create complex patterns of tree survival. In a small area of large, old forest in the midst of the floodplain patch we observed along the Rayas River (near FF02, Fig. 2), deposits 0.1 to $1.0 \mathrm{~m}$ thick killed little vegetation in part because forest floor micro-topography exceeded a meter of 
relief. Old, large-diameter $(>1 \mathrm{~m})$, downed logs with a dense cover of plants protruded above the deposits and supported lush vegetation cover. Living old trees were ringed by their own bark-slough mounds and appeared to stand on a floodplain surface less than a meter above the new deposits. Forests along tributaries of the Rayas River draining the north-flank blast zone also experienced tree mortality where post-eruption fluvial and debris-flow deposits inundated floodplain surfaces. However, in these steep channels, patterns of tree mortality (Fig. 6) were more complex than on floodplain surfaces along the larger rivers, because topography on the scale of a few meters along the tributary channels created greater spatial complexity of deposit thickness. Delayed browning of the tree canopy similar to that along the Rayas River was also observed along the tributaries draining the blast zone (Figs. 5, 6).

\subsubsection{Pyroclastic flow of 19 February 2009}

Spatial patterns of vegetation damage in the zone of pyroclastic flow deposition on floodplains were complex and involved heating, abrasion, and impact force as well as burial. The partial dome collapse on 19 February 2009 sent a pyroclastic flow to the south along Caldera Creek and down the Chaitén River to within $3 \mathrm{~km}$ of the town (Major et al., 2013, this volume). This pyroclastic flow covered a portion of the Chaitén River valley floor, in part overriding the area inundated by the flooding of 12-14 May 2008. It also flowed into living forest, burying it to a depth of up to about $8 \mathrm{~m}$ (Major et al., 2013, this volume). The pyroclastic flow subjected the inundated forest to high impact force and severe abrasion, but some areas experienced only tranquil deposition, which permitted standing trees to be encased by the flow and charred by the deposit. The parts of trees extending above the deposit, however, were not charred. Subsequent fluvial erosion exposed these partially buried trees, revealing the charred trunks. The intact tree tops with full branch systems then fell adjacent to the trunk in random directions, indicating that they had fallen after the erosion event and had not been transported from the site (Fig. 16). One ecological consequence of this superposition of pyroclastic flow deposition over fluvial deposition is that trees that might have survived fluvial deposition around their bases did not survive deposition of hot pyroclastic deposits. The areas of thick pyroclastic-flow deposits were devoid of living vegetation in 2010, but the substantial legacies of dead organic matter will influence vegetation succession.

\section{Discussion}

\subsection{Overview of disturbance mechanisms at Chaitén}

The 2008-2009 eruption of Chaitén involved a diverse suite of volcanic and hydrologic processes that affected forest vegetation. The varied disturbance mechanisms (Table 1) resulted in a complex array of initial ecological impacts of varying areal extent. All geophysical processes included a significant component of burial. Thermal stress (heat) was the dominant disturbance mechanism in the smallest disturbance zone (the narrow scorch zone on the north flank of the volcano); in other disturbance zones there was either no thermal stress, other processes overprinted the evidence of thermal stress, or thermal stress was just one of several mechanisms that contributed to forest damage. By creating the tree-removal and toppled-tree zones, the impact force of the blast affected a larger area than scorching alone. Floodplain deposition and burial of forest affected a comparable or slightly larger area than impact force. Abrasion of tree canopies by gravel rain affected a larger area than the zones dominated by impact force or burial of floodplain forest. Canopy loading by accumulated air fall tephra affected an area an order-of-magnitude larger. This area included partial canopy loading and collapse in areas that received 10 to $20 \mathrm{~cm}$ of tephra, and complete collapse and breakage of the canopy in areas that received $>50 \mathrm{~cm}$ of tephra. Knowledge of the extent of the zone of $>50 \mathrm{~cm}$ tephra fall is severely limited by access. Acid deposition on foliage may have originated from degassing of the lava dome over many months (Lowenstern et al., 2012), affecting an area of unknown extent. Acid deposition may have affected vegetation within a few kilometers of the vent, but physical effects of tephra may have precluded or masked any chemical effects. Further work on possible chemical effects of eruptions on forest damage is warranted. Such work should distinguish between effects on foliage during the period of tephra fall and effects on foliage that sprouted after tephra fall ceased, but while volcanic degassing continued. Study of lichens, which are commonly used in air quality assessment, is also highly relevant to detecting gas emissions. 


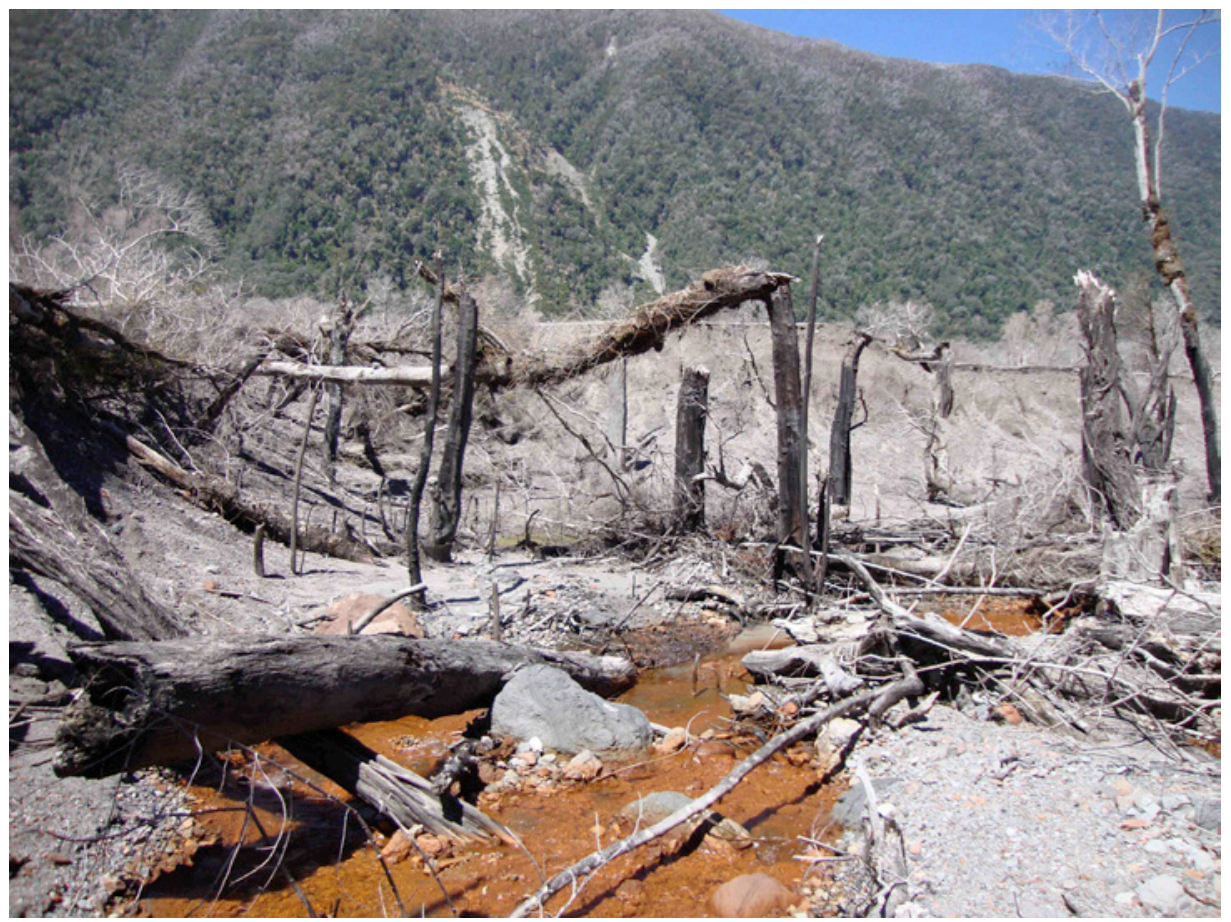

FIG. 16. Remnants of forest buried by the pyroclastic flow of 19 February 2009 along the Chaiten River valley, downstream of the confluence with Caldera Creek. Upright trunks are charred up to the top of the deposit, where the tree tops are broken. The fallen treetop in the center of the picture is covered with lianas that were not charred. Erosion subsequent to the pyroclastic flow has exposed these trunks. (Photo: J. Jones, January 2010).

Tree mortality varied substantially across the disturbance zones. In three zones, all trees were killed: the highest impact zones near the rim of the caldera in the blast zone; in sites of greater than $50 \mathrm{~cm}$ of tephra fall; and in the area of pyroclastic flow deposition along the Chaitén River. However, in most of the area affected by the eruption, mortality was partial and trees survived, as indicated by sprouting. In the blast zone, mortality ranged from complete near the rim, to 71 to $86 \%$ in the lower toppled-tree zone, to $24 \%$ in the scorch zone. Young forest on floodplains buried by 1 to $2 \mathrm{~m}$ of fluvial deposits had mortality ranging from $50 \%$ to over $80 \%$. Tephra deposition exceeding $50 \mathrm{~cm}$ caused complete tree mortality, but deposition of 10 to $15 \mathrm{~cm}$ of fine tephra caused only 2 to $10 \%$ mortality, and deposition of $<10 \mathrm{~cm}$ of fine tephra led to negligible mortality. Deposition of $15 \mathrm{~cm}$ of gravel tephra plus an additional $10 \mathrm{~cm}$ of sandy tephra resulted in tree mortality of 13 to $35 \%$.

Sprouting of damaged trees, which was common in many disturbance zones, indicates initial tree survival, but it may not signal long-term survival. In most areas affected by the eruption, surviving sprouting trees may play an important role in secondary succession. However, partial to complete mortality of sprouts observed in the second to fifth years after the eruption suggests that some tree mortality may be delayed by several years. Delayed mortality may occur because a small leaf area of sprouts is unable support a large, severely damaged tree.

The pattern of sprouting in relation to tree structure provides evidence of disturbance mechanisms. For example, the paucity of sprouting from small branches and twigs in the north-flank scorch zone suggests that the heat from the blast current may have killed buds beneath thin bark and at branch tips. Greater sprouting from trunks than from branches or twigs in the gravel-rain zone suggests that abrasion may have killed much of the canopy. Uprooting of trees in the blast/toppled-tree zone provided the opportunity for sprouting from the underside of rootwads and the up-turned, pre-eruption soil surface. Species vary in their ability to sprout from these various locations. 


\subsection{Comparison of volcanic and non-volcanic disturbance mechanisms}

The disturbance mechanisms associated with a volcanic eruption may be similar to or very different from mechanisms imposed by non-volcanic disturbances that occur more frequently in a given area. Combined with the concept of 'disturbance regime' (the frequency, severity, and geographic extent of disturbances), disturbance mechanisms provide a conceptual framework for comparing and contrasting disturbances.

Forests of the Chaitén region experience many non-volcanic disturbance processes, including heavy, wet snowfall; high winds; floods; debris slides; and episodic wildfire. These processes involve disturbance mechanisms that affect forests in ways similar to processes involved in the 2008-2009 Chaitén eruption. Heavy, wet snowfall is similar to airfall tephra: it loads the canopy and may produce extensive branch fall. High winds can topple patches of forest much like toppling in a volcanic blast, although wind disturbance lacks the sediment deposition and thermal effects of a volcanic blast. Wildfire commonly creates a perimeter of scorched foliage where sprouting may occur (Baker 2009), much like the scorch zone at Chaitén. The remarkable survival of components of the floodplain forest, despite burial by $>1 \mathrm{~m}$ of fluvially redeposited tephra, may represent adaptation of those tree species to episodic overbank sediment deposition that occurs during more frequent non-volcanic flooding.

The similarities between infrequent volcanic and more frequent non-volcanic processes have two implications. First, some frequent disturbance processes may involve disturbance mechanisms similar to those in very infrequent volcanic processes. For example, canopy loading from heavy, wet snow may prune branches in forests near Chaitén every decade or so, but much heavier canopy loading by tephra deposition could produce greater branch pruning. The high rates of branch fall in old forests in response to 15 to $20 \mathrm{~cm}$ of fine tephra fall at Chaitén suggest that (1) pruning by other processes had not been significant in recent years, leaving many branches available for collapse, or (2) the weight of rain-soaked tephra in the canopy was extraordinary. Another example of similarities and differences among volcanic and non-volcanic processes concerns burial of floodplain forests: although floodplain forests may experience frequent sediment deposition, tephra fall may contribute exceptional volumes of sediment in source watersheds, resulting in extraordinarily thick overbank deposits that contribute to higher floodplain forest mortality. A second implication of the similarity of mechanisms between volcanic and non-volcanic disturbance processes is that, on an evolutionary time scale, frequent disturbance by non-volcanic processes may have selected for species adaptations to disturbance mechanisms that also operate during infrequent volcanic disturbance, such as a blast. For example, heating by wildfire may select for tree species capable of sprouting from tree trunks and major branches in response to scorch during a volcanic disturbance.

Physical interaction of tephra fall with tree canopies involves a poorly understood interplay between properties of the tephra (e.g., size distribution, density, water content) and the vegetation (e.g., architecture, strength). At Chaitén fine tephra was delivered to forests mainly over the initial two weeks of the eruption. During this period tephra was deposited on foliage and other canopy structures, such as twig and branch systems and canopy epiphytes. Tephra, leaves, and branches may fall to the forest floor because of (1) breakage due to the weight of tephra possibly combined with its water content, (2) leaf abscission resulting from tephra interference with leaf water and energy balances (Segura et al., 1994, 1995), and (3) wind. Like precipitation intercepted in tree canopies (e.g., Pypker et al., 2006), the volume of tephra temporarily stored in the canopy may experience a dynamic balance of additions (from continued tephra fall) and losses (to the forest floor).

\subsection{Landscape patterns of overlapping distur- bance mechanisms}

Explosive volcanic eruptions, such as Chaitén 2008-2009 and Mount St. Helens 1980, commonly involve several geophysical processes that alter ecosystems in the surrounding landscape. Invariably, many of these process overlap in time and space. This presents an unusual challenge and opportunity for studies in disturbance ecology and associated landscape ecology, which have typically focused narrowly on individual processes, such as wildfire or insect defoliation, and generally do not consider diverse process types and their overlapping effects. 
Spatial and to some degree temporal overlap of processes with differing effects on biota create situations in which (1) disturbance effects are compounded and (2) effects of an earlier event may preclude effects of subsequent events. In the Chaitén River, for example, the pyroclastic flow of 19 February 2009 deposited volcanic sediment that further buried, and heated, floodplain forests, compounding the effects of earlier floodplain burial by flood and airfall tephra deposits. If acid deposition occurred (Lowenstern et al., 2012), its effects may have been precluded in the first years after the eruption because foliage had been removed by abrasion or canopy loading.

\subsection{Comparisons with Mount St. Helens}

Similarities and distinctions among vegetation disturbances caused by the eruption of Chaitén and those caused by the well-studied 1980 eruption of Mount St. Helens highlight initial interactions between physical processes and vegetation (Dale et al., 2005). Geographic similarities between these two areas include cool, wet, mid-latitude climate; some overlap of types of geophysical processes involved in the eruptions; and extensive forest cover dominated by native evergreen species in landscapes that experienced limited development before and after the eruptions, so that natural processes persist.

Both eruptions involved extensive tephra fall exceeding $5 \mathrm{~cm}$ thickness. However, branch fall from canopy loading and abrasion of foliage by gravel tephra, which were common in certain areas at Chaitén, were not observed to be significant at Mount St. Helens. The absence of branch fall at Mount St. Helens may be due to a higher proportion of light-weight pumice in the Mount St. Helens tephra; greater strength of the wood or architecture of Pacific Northwest United States conifers; conifer foliage structure that limits tephra entrainment; and/ or frequent heavy, wet snowfall, which may 'train' tree crowns to withstand infrequent tephra falls. The laterally directed blast at Mount St. Helens affected $550 \mathrm{~km}^{2}$, more than 100 times the area of the Chaitén blast, but both events produced a gradient of vegetation damage from tree removal to toppling to scorching of foliage and epiphytes. Mapping and interpretation of the tree-removal zone at Mount St. Helens were complicated by inclusion of areas with many causes of tree removal, including pre-eruption forest cutting (Lipman and Mullineaux, 1981, Plate 1). Similarly, sliding of vegetation, soil, and tephra down very steep slopes occurred at the transition from the tree-removal to toppled-tree zones at Chaitén, complicating interpretation of effects of the blast alone. As at Chaitén, some geophysical processes at Mount St. Helens precluded opportunity to observe the signature of subsequent processes on forests. At Mount St. Helens, exceedingly hot $\left(\mathrm{ca} .700^{\circ} \mathrm{C}\right.$; Banks and Hoblitt, 1981) pyroclastic flows encountered a landscape where forest had been obliterated already by a huge debris avalanche and blast, so it was not possible to observe effects of pyroclastic flows on forests. Similarly, massive lahars raced down all major river channels draining Mount St. Helens; hence, subsequent deposition of fluvially transported sediment on forested floodplains occurred on sites already highly modified. Chaitén Volcano lacked the water and sediment supply to produce massive lahars like those generated at Mount St. Helens.

Similarities and differences of ecological properties of the landscapes influenced biological responses to these two eruptions. Several tree species at Chaitén have the ability to sprout after falling or being battered or scorched, whereas conifers at Mount St. Helens could not sprout, so they died immediately. At both Chaitén and Mount St. Helens, biological legacies in the forms of dead organic matter and surviving individual plants, animals, and fungi persist to influence development of new ecosystems in most of the disturbance zones. Further work is needed to track ecological responses at Chaitén for comparison with the more than three-decade posteruption record at Mount St. Helens.

Study of major ecosystem disturbance events, such as volcanic eruptions, benefits from three ingredients: immediate, sustained, and interdisciplinary effort, to achieve the potential to grow geological and ecological knowledge and to strengthen hazard mitigation and management of natural resources. Early post-eruption studies are essential to detect geophysical and ecological evidence of initial events that may be quickly lost, yet may be critical for understanding both initiating processes and also longer-term developments. Long-term study is important because the physical and biotic landscapes change both gradually and abruptly after major disturbances; and secondary events, such as floods and insect outbreaks, may strongly influence the 
system. An interdisciplinary view is essential because physical and ecological components of the landscape are developing independently and synergistically, so careful, sustained observations from many points of view are essential to sorting out cause and effect over decades. Interdisciplinary field campaigns, such as the one described by Pallister et al. (2010) for Chaitén, can prove especially fruitful. From such interdisciplinary efforts a field of volcano ecology is emerging.

\section{Conclusions}

Volcanic and associated hydrological processes during the 2008-2009 eruption of Chaitén damaged forest vegetation in ways that reveal properties of those processes and also clues to geographic patterns and long-term processes of biological response. Vegetation damage and immediate growth response (e.g., sprouting) can be interpreted in terms of physical mechanisms of forest damage: lateral impact force, heat, deposition, abrasion, and loading of tree canopies. Each type of volcanic process involves a suite of these mechanisms; therefore, combinations of mechanisms in various portions of the landscape can be characterized as distinctive disturbance zones, which at Chaitén included a directed blast (with treeremoval, toppled-tree, and scorch sub-zones), coarseand fine-textured tephra fall, floodplain deposition of remobilized tephra, and pyroclastic-flow zones. Despite the many types and intensities of damage to ecosystems, plants survived and dead organic matter persisted in many disturbance zones; these biological legacies are initiating secondary succession and soil development. Only a few areas of very limited extent experienced such severe disturbance that they are undergoing primary succession in the absence of any biological legacy of the pre-eruption ecosystem. Rapid, sustained, and highly interdisciplinary examination of interactions of volcanic events and vegetation in the landscape surrounding active volcanoes can inform both biological and geological sciences and their service to society.

\section{Acknowledgments}

We thank M. González (Universidad Austral de Chile) for ecological perspectives, N. LaPenna (Chaitur, Chaitén) for great help with field operations, D. Guzmán (Pumalín Park) for access and information, N. Carrasco (Universidad Austral de Chile) for technical advice during field studies, and J. Muñoz (SERNAGEOMIN) for technical support. We thank J. Major for consultation in many phases of this work; E. Miles, K. Miles, P. Nelson, and T. Wheeler for field collaborations; and K. Christiansen and C. Weems for GIS work and figure production. We greatly appreciate support of United States Forest Service International Programs and the Pacific Northwest Research Station, and the National Science Foundation (grants NSF 0917697 and NSF 0823380 ). The opportunity to collaborate with United States Geological Survey and SERNAGEOMIN colleagues has been extremely helpful, especially during the 2010 field campaign.

\section{References}

Alfano, F.; Bonadonna, C.; Volentik, A.C.M.; Connor, C.B.; Watt, S.F.L.; Pyle, D.M.; Connor, L.J. 2011. Tephra stratigraphy and eruptive volume of the May, 2008, Chaitén eruption, Chile. Bulletin of Volcanology 73 (5): 613-630.

Andrews, B.J.; Manga, M. 2011. Effects of topography on pyroclastic density current runout and formation of coignimbrites. Geology 39: 1099-1102.

Ayris, P.M.; Delmelle, P. 2012. The immediate environmental effects of tephra emission. Bulletin of Volcanology 74: 1905-1936.

Baker, W.L. 2009. Fire Ecology in Rocky Mountain Landscapes. Island Press: 628 p. Washington.

Banks, N.G.; Hoblitt, R.P. 1981. Summary of temperature studies of 1980 deposits. In The 1980 Eruptions of Mount St. Helens, Washington. (Lipman, P.W.; Mullineaux, D.R.; editors). United States Geological Survey, Professional Paper 1250: 295-313.

Carn, S.A.; Pallister, J.S.; Lara, L.; Ewert, J.W.; Watt, S.; Prata, A.J.; Thomas, R.J.; Villarosa, G. 2009. The unexpected awakening of Chaitén Volcano, Chile. Eos, Transactions of the American Geophysical Union 90 (24): 205-206.

Dale, V.H.; Swanson, F.J.; Crisafulli, C.M. (editors). 2005. Ecological Responses of the 1980 Eruption of Mount St. Helens. Springer Science: 342 p. New York.

Donoso, C. 2008. Arboles nativos de Chile. María Cuneo Ediciones: 136 p. Valdivia.

Donoso, C.; Ramírez, C. 1994. Arbustos Nativos de Chile. María Cuneo Ediciones: 119 p. Valdivia.

Garreaud, R.D. 2009. The Andes climate and weather. Advances in Geosciences 22: 3-11.

Garreaud, R.; López, P.; Minvielle, M.; Rojas, M. 2013. Large scale control on the Patagonia climate. Journal of Climate 26: 215-231. 
Holz, A.; Kitzberger, T.; Paritsis, J.; Veblen, T.T. 2012. Ecological and climatic controls of modern wildfire activity patterns across southwestern South America. Ecosphere 3 (11): 25 p. doi: 10.1890/ ES12-00234.1.

Hudspith, V.A.; Scott, A.C.; Wilson, C.J.N.; Collinson, M.E. 2010. Charring of woods by volcanic processes: An example from the Taupo ignimbrite, New Zealand. Palaeogeography, Palaeoclimate, Palaeoecology 291: 40-51.

Kelfoun, K.; Legros, K.; Gourgaud, A. 2000. A statistical study of trees damaged by the 22 November 1994 eruption of Merapi Volcano (Java, Indonesia): relationships between ash-cloud surges and block-and-ash flows. Journal of Volcanology and Geothermal Research 100: 379-393.

Lara, L.E. 2009. The 2008 eruption of the Chaitén Volcano, Chile: a preliminary report. Andean Geology 36 (1): 125-129.

Lipman, P.W.; Mullineaux, D.R. (editors). 1981. The 1980 Eruptions of Mount St. Helens, Washington. United States Geological Survey, Professional Paper 1250: $844 \mathrm{p}$.

Lowenstern, J.B.; Bleick, H.; Vázquez, J.A.; Castro, J.M.; Larson, P.B. 2012. Degassing of Cl, F, Li and Be during extrusion and crystallization of the rhyolite dome at Volcán Chaitén, Chile during 2008 and 2009. Bulletin of Volcanology 74 (10): 2303-2319.

Major, J.J.; Lara, L.E. 2013. Overview of Chaitén Volcano, Chile, and its 2008-2009 eruption. Andean Geology 40 (2): 196-215.

Major, J.J.; Pierson, T.C.; Hoblitt, R.P.; Moreno, H. 2013. Pyroclastic density currents associated with the 2008-2009 eruption of Chaitén Volcano (Chile): Forest disturbances, deposits, and dynamics. Andean Geology 40 (2): 324-358.

Moore, J.G.; Sisson, T.W. 1981. Deposits and effects of the May 18 pyroclastic surge. In The 1980 Eruptions of Mount St. Helens, Washington (Lipman, P.W.; Mullineaux, D.R.; editors). United States Geological Survey, Professional Paper 1250: 421-438.

Pallister, J.S.; Diefenbach, A.K.; Burton, W.C.; Muñoz, J.; Griswold, J.P.; Lara, L.E.; Lowenstern, J.B.; Valenzuela, C.E. 2013. The Chaitén rhyolite lava dome: Eruption sequence, lava dome volumes, rapid effusion rates and source of the rhyolite magma. Andean Geology 40 (2): 277-294.

Pallister, J.S.; Major, J.J.; Pierson, T.C.; Hoblitt, R.P.; Lowenstern, J.B.; Eichelberger, J.C.; Lara, L.; Moreno, H.; Muñoz, J.; Castro, J.M.; Iroumé, A.; Andreoli, A.;
Jones, J.; Swanson, F.; Crisafulli, C. 2010. Interdisciplinary studies of eruption at Chaitén Volcano, Chile. Eos, Transactions of the American Geophysical Union 19 (42): 381-382.

Peters, D.P.C.; Lugo, A.E.; Chapin, F.S.; Pickett, S.T.A.; Duniway, M.; Rocha, A.V.; Swanson, F.J.; Laney, C.; Jones, J. 2011. Cross-system comparisons elucidate disturbance complexities and generalities. Ecosphere 2 (7): 3-26. doi: 10.1890/ES11-00115.1.

Pierson, T.C.; Major, J.J.; Amigo, Á.; Moreno, H. 2013. Acute sedimentation response to rainfall following the explosive phase of the 2008-2009 eruption of Chaitén Volcano, Chile. Bulletin of Volcanology 75, 723: 17 p. doi: 10.1007/s00445-013-0723-4.

Pypker, T.G.; Unsworth, M.H.; Bond, B.J. 2006. The role of epiphytes in rainfall interception by forests in the Pacific Northwest. II. Field measurements at the branch and canopy scale. Canadian Journal of Forest Research 36: 819-832.

Segura, G.; Hinckley, T.M.; Brubaker, L.B. 1995. Variations in radial growth of declining old-growth stands of Abies amabilis after tephra deposition from Mount St. Helens. Canadian Journal of Forest Research 25 (9): 1484-1492.

Segura, G.; Brubaker, L.B.; Franklin, J.F.; Hinckley, T.M.; Maguire, D.A.; Wright, G. 1994. Recent mortality and decline in mature Abies amabilis: the interaction between site factors and tephra deposition from Mount St. Helens. Canadian Journal of Forest Research 24 (6): 1112-1122.

Swanson, F.J.; Collins, B.; Dunne, T.; Wicherski, B.P. 1983. Erosion of tephra from hillslopes near Mt. St. Helens and other volcanos. In Proceedings of the Symposium on Erosion Control in Volcanic Areas. 1982 July 6-9; Seattle and Vancouver, WA. Japan Ministry of Construction, General Technical Memorandum 1908: 183-221.

Swanson, F.J.; Major, J.J. 2005. Physical events, environments, and geological-ecological interactions at Mount St. Helens: March 1980-2004. In Ecological Responses to the 1980 Eruption of Mount St. Helens. (Dale, V.H.; Swanson, F.J.; Crisafulli, C.M.; editors). Springer: 27-44. New York.

Veblen, T.T.; Schlegel, F.M.; Oltremari, J.V. 1983. Temperate broad-leaved evergreen forests of South America. In Temperate Broad-Leaved Evergreen Forests (Ovington, J.D.; editor). Elsevier: 5-31. Amsterdam.

Veblen, T.T.; Donoso, C.; Kitzberger, T.; Rebertus, A.J. 1996. Ecology of southern Chilean and Argentinean 
Nothofagus forests. In The Ecology and Biogeography of Nothofagus Forests (Veblen, T.T.; Donoso, C.; Rebertus, T.; editors). Yale University Press: 293-353. New Haven.

Voight, B.; Davis, M.J. 2000. Emplacement temperatures of the November 22, 1994 nuée ardente deposits, Merapi Volcano, Java. Journal of Volcanology and Geothermal Research 100: 371-377.

Watt, S.F.L.; Pyle, D.M.; Mather, T.A.; Martin, R.S.; Matthews, N.E. 2009. Fallout and distribution of volcanic ash over Argentina following the May 2008 explosive eruption of Chaitén, Chile. Jour- nal of Geophysical Research 114 (B04207). doi: 10.1029/2008JB006219.

White, P.S.; Pickett, S.T.A. 1985. Natural disturbance and patch dynamics: an introduction. In The Ecology of Natural Disturbance and Patch Dynamics (Pickett, S.T.A.; White P.S.; editors). Academic Press: 3-13. New York.

Winner, W.E.; Casadevall, T.J. 1981. Fir leaves as thermometers during the May 18 eruption. In The 1980 Eruptions of Mount St. Helens, Washington (Lipman, P.W.; Mullineaux, D.R.; editors). United States Geological Survey, Professional Paper 1250: 315-320. 